\title{
Innovative Seals for Solid Oxide Fuel Cells (SOFC)
}

Final Progress Report

For the Period September 15, 2004 to June 30, 2008

DOE Award \# DE-FC26-04NT42227

\section{Submitted to}

\author{
U.S. Department of Energy \\ National Energy Technology Laboratory \\ 625 Cochrans Mill Road, P.O. Box 10940 \\ Pittsburgh, PA 15236-0940 \\ Attn: Ms. Anne Cary, Contract Specialist \\ E-MAIL: Anne.Cary@netl.doe.gov
}

Program Manager: A. Manivannan

\section{Prepared by}

\section{Professor Raj N. Singh \\ Principal Investigator}

Department of Chemical and Materials Engineering

University of Cincinnati, P.O. Box 210012

Cincinnati OH 45221-0012

Phone: (513) 556-5172, Fax: (513) 556-3773, Email: Raj.Singh@ UC.Edu

Report Issue Date: September 28, 2008 


\section{DE-FC26-04NT42227 - Innovative Seals for Solid Oxide Fuel Cells (SOFC)}

\section{DISCLAIMER}

"This report was prepared as an account of work sponsored by an agency of the United States Government. Neither the United States Government nor any agency thereof, nor any of their employees, makes any warranty, express or implied, or assumes any legal liability or responsibility for the accuracy, completeness, or usefulness of any information, apparatus, product, or process disclosed, or represents that its use would not infringe privately owned rights. Reference herein to any specific commercial product, process, or service by trade name, trademark, manufacturer, or otherwise does not necessarily constitute or imply its endorsement, recommendation, or favoring by the United States Government or any agency thereof. The views and opinions of authors expressed herein do not necessarily state or reflect those of the United States Government or any agency thereof." 


\section{DE-FC26-04NT42227 - Innovative Seals for Solid Oxide Fuel Cells (SOFC)}

\section{Executive Summary}

Seals continue to be the top priority of the SECA-CTP (Core Technology Program). This final report is prepared to describe the progress in the program on innovative high temperature seals for SOFC. In particular, a new concept of self-healing glass seals was pursued for making seals between metal-ceramic material combinations, including some with a significant expansion mismatch. The overall objectives of the program were to develop, characterize, and demonstrate innovative solid oxide fuel cell (SOFC) sealing concepts based upon self-healing glass-metal seals. Specific tasks for Phase I included (1) develop and test glasses exhibiting self-healing behavior under SOFC operating conditions, (2) further develop, and characterize properties and stability of glasses displaying self-healing behavior, (3) demonstrate fiber reinforcement of glasses for potential applications as mechanically tough glass seals, and (4) conduct a survey of commercially-available glasses suitable for use as seals in SOFCs. Self-healing seals and sealing materials were further developed and tested over a longer time periods under conditions typical of SOFCs in Phase II to validate the long-term stability. These activities are expected to create a reliable and stable sealing system for the SOFC and SECA program to realize the goal of 40,000 hours of SOFC life.

A novel concept of in situ crack healing by glasses is developed and used to make seals. The fundamental idea underlying this concept is based on the fact that a glass with suitable thermophysical property and viscosity can heal cracks created because of the thermal expansion mismatch between materials that are being joined by a glass seal in a SOFC. The functionality of this innovative sealing approach based on in situ crack healing by a glass has been successfully demonstrated and quantified. A number of glasses were selected for demonstration of the self-healing behavior and potential for making seals that display self-healing response. These glasses were fabricated and their structure, thermophysical properties (expansion), densification behavior, and wetting behavior with YSZ electrolyte, Crofer, SS 430, and Nickel metals were determined for suitability of making seals. Based on these characterizations the more promising glasses are further selected for making seals. Sintered samples of glasses and YSZ are fabricated for the program by developing procedures for tape casting of glasses and YSZ, sintering procedures to make dense YSZ and glasses, and preparation of metals appropriate for making seals

A new methodology based on video imaging of cracks were applied to characterize self-healing behavior of all the selected glasses and glass-ceramics as a function of temperature and time. The analysis of the crack-healing data is used to arrive at the self-healing temperature-time history for use in self-healing of the glass seals. This also provided information on the suitability of the glasses for providing self-healing capability. Generally, glass-ceramics showed slower selfhealing kinetics than the glassy state but the exact kinetics is dependent on the specific glass or glass-ceramics.

A seal test system was designed and built for testing seals both at room and elevated temperatures up to $1200^{\circ} \mathrm{C}$. The system has facilities for continuously monitoring pressure as a function of time from which leak rates are determined. This facility is extensively used in developing hermetic seals that display self-healing behavior. Seals incorporating some of the 


\section{DE-FC26-04NT42227 - Innovative Seals for Solid Oxide Fuel Cells (SOFC)}

more promising glasses are fabricated. Extensive efforts are expended on developing seals that show hermetic response both at room and elevated temperatures. Effect of thermal cycles between 25 and $800^{\circ} \mathrm{C}$ on hermeticity of the seals is demonstrated. Heating the seals to SOFC operating temperatures and then measuring the leak behavior, which demonstrated recovery of the hermeticity after self-healing treatments, demonstrate self-healing behaviors of the leaking seals. Seals are also tested extensively at higher temperatures between $25-800^{\circ} \mathrm{C}$ and displayed hermetic behavior at each of the temperatures.

Thermal stability of the sealing glasses are determined by annealing glasses alone and glassmetal, and glass-YSZ couples at $800^{\circ} \mathrm{C}$ for times up to 500 hours. The thermophysical and thermochemical stability of the glasses against reaction and crystallization are determined. The results displayed insignificant changes in properties from the as-fabricated state indicating stability of the promising sealing material systems.

Extensive testing of the seals comprising of Crofer-glass-YSZ at high temperatures of $800^{\circ} \mathrm{C}$ and under thermal cycling between $25^{\circ}$ and $800^{\circ} \mathrm{C}$ is performed. This included demonstration of the self-healing behavior, short-term and extended-time leak testing at each of the temperatures, thermal cycling, and the effect of test atmosphere (including dual atmosphere) on the leak performance. The seal has accumulated 3000 hours of testing at $800^{\circ} \mathrm{C}$, has undergone over 300 thermal cycles, and remains hermetic.

The self-healing glass seals were further developed in Phase II of the proposed program. The major goal of this phase was to determine longer-term stability of the self-healing seals developed in Phase-I of the program. The following are some of the important findings of the program. There has been a redirection of efforts in mid-course.

Developed self-healing glasses for making seals for SOFC. The seals were tested for leak at $800^{\circ} \mathrm{C}$ and demonstrated self-healing ability for tests performed for 3000 hours and 300 thermal cycles in a variety of test environments typical of a SOFC. Self-healing glasses have shown stability against crystallization in seal tests for 3000 hours, and in thermal annealing tests in air and moist fuel at $800^{\circ} \mathrm{C}$ for 1700 hours. In situ X-ray diffraction of glasses at temperatures between $25-800^{\circ} \mathrm{C}$ displayed no crystal phases in tests performed at NETL. The weight loss experiments performed in moist fuel environment at $800^{\circ} \mathrm{C}$ for 500 hours displayed insignificant weight loss. A weight loss of $0.53 \%$ over 40,000 hours is calculated from extrapolated data. Analyses of samples after annealing by XPS depth profiling indicated little change in elemental depth profile after annealing. DC electrical resistivity of the self-healing glass between $25-800^{\circ} \mathrm{C}$ is measured with a value of $0.6 \times 10^{6} \mathrm{Ohm}-\mathrm{cm}$ at $800^{\circ} \mathrm{C}$. Creep tests were performed on a selfhealing glass to determine glass flow behavior and the data were used to calculate glass viscosity useful in modeling response of the sealing glass in a SOFC stack. Initiated redirected program and measured compatibility and electrical properties of glass in contact with coated $441 \mathrm{SS}$.

Fabricated $2 \mathrm{~kg}$ of glass and shipped to ORNL on August 27, 2009 per program goals. 


\section{Table of Contents}

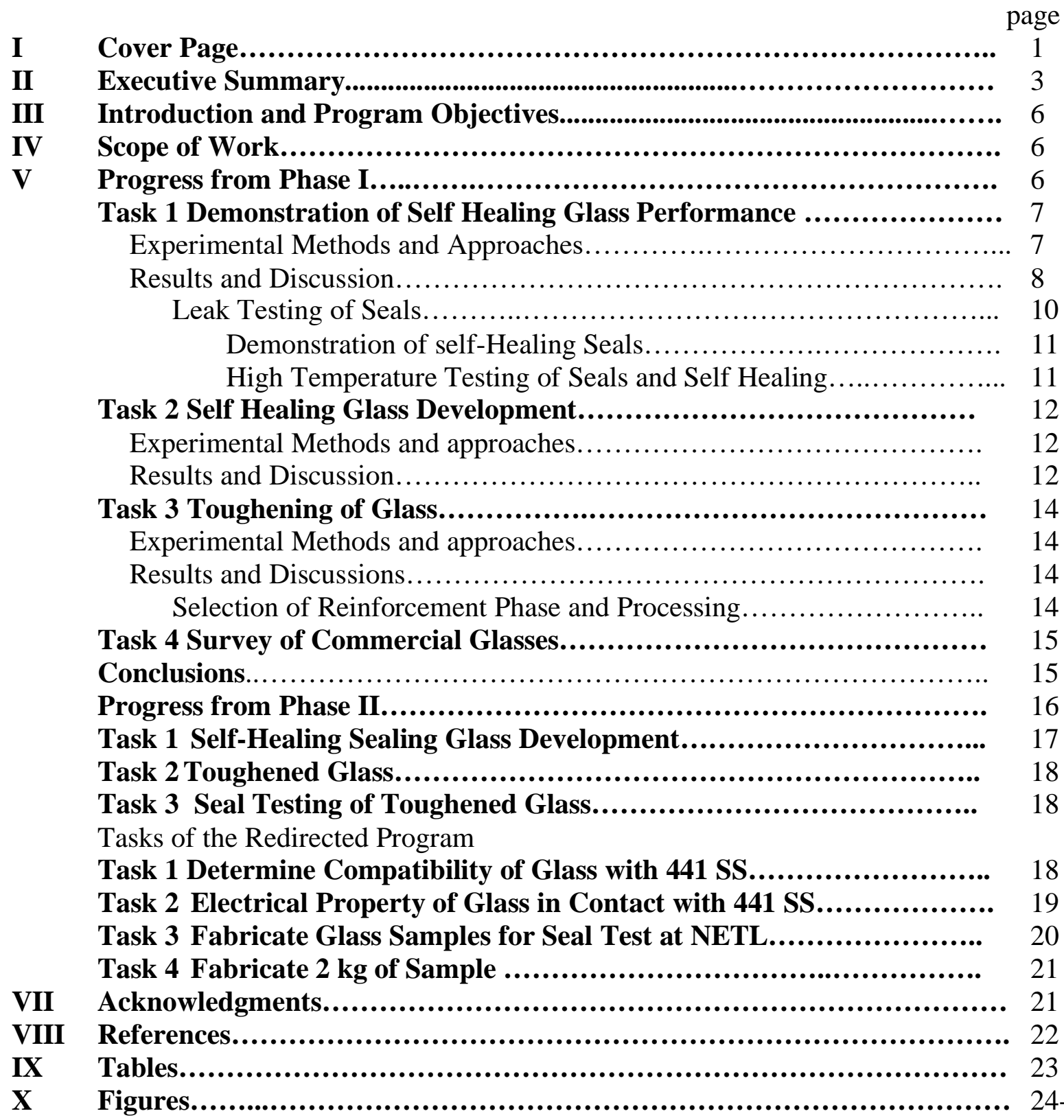




\section{DE-FC26-04NT42227 - Innovative Seals for Solid Oxide Fuel Cells (SOFC)}

\section{Introduction and Program Objectives}

A functioning SOFC requires different type of seals such as metal-metal, metal-ceramic, and ceramic-ceramic (1-14). These seals must function at high temperatures between $600-900^{\circ} \mathrm{C}$ and in oxidizing and reducing environments of the fuels and air. Among the different type of seals, the metal-metal seals can be readily fabricated using metal joining, soldering, and brazing techniques. However, the metal-ceramic and ceramic-ceramic seals require significant research and development because the brittle nature of ceramics/glasses can lead to fracture and loss of seal integrity and functionality. Consequently, any seals involving ceramics/glasses require a significant attention and technology development for reliable SOFC operation. This final report is prepared to describe the progress made in the program on the needs, approaches, and performance of high temperature seals for SOFC. In particular, a new concept of self-healing glass seals is pursued for making seals between metal-ceramic material combinations, including some with a significant expansion mismatch.

The overall objectives of the Phase I program are to develop, characterize, and demonstrate innovative solid oxide fuel cell (SOFC) sealing concepts based upon glass-metal seals. Specific tasks include (1) developing and testing of glasses exhibiting self-healing behavior under SOFC operating conditions, (2) further develop, and characterize properties and stability of glasses displaying self healing behavior, (3) demonstrate fiber reinforcement of glasses for potential applications as mechanically tough glass seals, and (4) conduct a survey of commerciallyavailable glasses suitable for use as seals in SOFCs and measuring selected properties of the promising commercial glasses. Seals and sealing materials were further developed and tested over a longer time periods under conditions typical of SOFCs in Phase II to validate the longterm stability. These activities are expected to create a reliable and stable sealing system for the SOFC program to realize the goal of 40,000 hours of SOFC life.

\section{Scope of Work}

A novel concept of in situ crack healing by glasses is developed and used to make seals in this program. The fundamental idea underlying this concept is based on the fact that a glass with suitable thermophysical property and low viscosity can heal cracks created because of the thermal expansion mismatch between materials that are being joined by a glass seal in a SOFC. The functionality of this innovative sealing approach based on in situ crack healing by a glass has been demonstrated and quantified. These concepts are pursued further to address sealing capabilities and durability issues related to a functioning glass seal for a SOFC. Toughening and strengthening of the glass by fibers/whiskers are also pursued to toughen the glass to minimize or eliminate bulk cracking of the glass seals. A survey of the commercially promising glasses for use in SOFCs was done to establish a database of available glasses and attendant properties. In addition, the data from Sandia National Laboratory, University of Missouri - Rolla, and PNL were integrated into this database.

\section{Progress from Phase I}




\section{DE-FC26-04NT42227 - Innovative Seals for Solid Oxide Fuel Cells (SOFC)}

All of the program goals related to Phase I were successfully met. This included selection of glasses, metals, and electrolyte materials suitable for these tasks, fabrication and/or purchase of these materials from vendors, processing of materials to fabricate samples suitable for property measurements and sealing studies, in situ characterization of the self-healing behaviors of glasses, fabrication of seals comprising of YSZ, metals, and glasses, leak testing of the seals at room and high temperatures, including the effect of thermal cycles. Self-healing behavior of seals was also tested via seal tests. In addition, facilities for leak testing, seal fabrication, and material properties measurements relevant to seals for SOFC were created. Fiber reinforcement of the glasses was done. Rationale for these activities and results to date on each Task are described in the following sections.

\section{Task 1: Demonstration of Self-Healing Glass Seal Performance}

Suitable glasses exhibiting self-healing behavior under SOFC operating conditions were selected and manufactured through commercial vendors based on our specifications. Processing of the seals was done by tape casting and lamination techniques. A test fixture was fabricated for leak testing in our laboratory. The seals were tested for leakage at room temperature, at SOFC operating temperatures (up to and including $800^{\circ} \mathrm{C}$ ), and after thermal cycling. Data on glass transition temperature $\mathrm{T}_{\mathrm{g}}$, coefficient of thermal expansion (CTE) vs. temperature, and leak rate vs. temperature, number of thermal cycles and pressure were generated. Metallography/SEM examinations were done to further characterize degradation. The self-healing behaviors of glasses were evaluated through high temperature imaging techniques. Cracks were initiated at a notch and then the sample was heated between $500-1000^{\circ} \mathrm{C}$ and the video images of the cracks were continuously recorded to demonstrate self-healing behavior.

\section{Experimental Methods/Approaches}

The primary focus of the project in Task 1 was to demonstrate self-healing glass seal performance. This involved selection of materials for the program, fabrication of glass seals suitable for self-healing performance, ordering components to construct leak test station, and demonstrating self-healing seals using this facility. A brief description and rationale for each of these activities is given below.

\section{Selection of Materials for Self-Healing Seals}

The goal of this task is to develop seals suitable for joining electrolyte (YSZ) to a metal using a glass that can show self-healing behavior. This requires selection of glasses with appropriate thermophysical properties such as softening temperature and expansion match with YSZ and metals. A number of glasses were considered and fabricated. Table 1 lists the glasses selected for self-healing seal development based on their thermophysical properties and glasstransition/softening temperatures. Some of these glasses (\# 2, 5, 6, 8, 9) are expected to crystallize to different degrees at or above $800^{\circ} \mathrm{C}$ to demonstrate the effect of crystallization on the self-healing behavior. Two of these Glasses (6 and 7) obtained as plates from University of Missouri (UMR) were also included in this list because of the good expansion match with electrolyte and ferritic steels based on the data from UMR. One of these glasses Glass- 6 is a glass-ceramic and the Glass-7 maintains its glassy character over a long time at low temperatures $\left(\sim 750^{\circ} \mathrm{C}\right)$. However, both of these glasses are expected to crystallize at higher temperatures 


\section{DE-FC26-04NT42227 - Innovative Seals for Solid Oxide Fuel Cells (SOFC)}

$\sim 800-900^{\circ} \mathrm{C}$. In addition, Glasses 8 and 9 were prepared by mixing Glass1 and YSZ to obtain a glass-ceramic with better expansion match with YSZ and possibly good wetting with the YSZ and metals because of the lower softening temperature of the Glass 1. These glasses were used in forming glass-metal contacts by placing each glass on metals (SS 430, Crofer, and Ni) and heating the samples between $600-900^{\circ} \mathrm{C}$ for study of the wetting behavior to further down select glasses for making seals as described later.

\section{Fabrication of Samples and Characterization}

Samples of glass powders were used for x-ray diffraction studies to insure that the starting materials are indeed amorphous in crystal structure. The glass and YSZ powders were then used for fabricating green tapes of glasses or YSZ using tape-casting techniques. These tapes were then used in processing of dense samples of YSZ by sintering. Density of the samples was measured after sintering. Expansion behaviors of all the samples, glasses, metals, and YSZ were measured between $25-1000^{\circ} \mathrm{C}$ in a high-temperature dilatometer interfaced with a $\mathrm{PC}$ for data collection. These data were then used to determine coefficient of thermal expansion of all materials, and glass transition and softening temperatures.

\section{Characterization of the Self-Healing Behavior of Glasses}

Cracks in ceramics and glasses can be healed by the diffusion processes at high temperatures as demonstrated by our past work [15]. Crystalline ceramics require higher temperatures for healing than some of the glasses because of the thermally activated nature of the diffusion process responsible for healing. There are two possible ways of characterizing crack healing in glasses suitable for sealing components of a SOFC. In one approach, heating at high temperatures can heal cracks created in a glass sample and the recovery of strength can be used as an evidence of the crack healing. Another way is to visually observe the cracks as they heal as a function of temperature to monitor healing behavior and kinetics. The second approach is more direct and does not rely on strength measurements, which is an indirect way to characterize self-healing. The second method is also simple and can give a direct measure of the temperature-time or kinetics of the healing process. This can then be used directly to assess the capabilities of a glass towards healing. This second approach was used to characterize healing behavior of glasses listed in Table 1 and then these information were used to affect self-healing at the seal level in this program. Towards this goal, bar-shaped samples of these glasses were fabricated by sintering for demonstration of the self-healing using a video-imaging facility. The self healing behavior was studied by heating the glass to desired temperatures between $25-1000^{\circ} \mathrm{C}$ and observing the surface of the glass sample with cracks by a video camera (in a unique facility) for detecting the temperature-time history of the self-healing process to begin and end. These data were used for selecting the processing temperatures for making the seals and appropriate conditions required for demonstration of the self-healing behavior.

\section{Results and Discussion}

X-ray diffraction patterns were obtained using a powder diffractometer to insure that the starting glasses were amorphous in crystal structure. Glasses 1-5 were used in this study because a commercial vendor based on our specifications manufactured these glasses. Glasses 6 and 7 were obtained from UMR as plates and assumed to be glassy based on data from UMR. Glasses 8 and 9 are mixtures of Glass 1 and YSZ so it is expected to be a glass-ceramics. The x-ray diffraction 


\section{DE-FC26-04NT42227 - Innovative Seals for Solid Oxide Fuel Cells (SOFC)}

patterns from Glasses 1-5 indicated that the initial glass powders are indeed amorphous in structure. The glass 1 starts to crystallize upon annealing at $800^{\circ} \mathrm{C}$ for 20 hours but all of the other glasses (\#2-5) maintained their amorphous nature after 20 hour anneal as shown by data for glass 4. Stability of glasses against crystallization at $800^{\circ} \mathrm{C}$ for 20 hours is essential for the rest of processing and testing of the self-healing behavior. Consequently, glass 1 was not pursued for the self-healing demonstration.

A robust seal between YSZ electrolyte and a metal using a glass requires good expansion matching of the glass with YSZ and metals. Consequently, characterization of the thermal expansion behavior of materials over a range of temperatures was necessary so that the material combinations showing the most promising seals can be pursued. Therefore, measurements of the expansion behavior of all the metals (Crofer, SS 430, Ni, and SS 304), glasses (1-9), and YSZ were done between $25-1000^{\circ} \mathrm{C}$. Figure 2 shows the expansion behavior of metals with SS 430 having the lowest expansion among the metals and SS 304 with the highest value. These data were used to calculate the coefficient of thermal expansion of these materials listed in Table 1. These results show that Crofer and SS 430 have coefficient of thermal expansion close to YSZ but actual values are temperature dependent and should be taken into considerations when considering materials combinations for making reliable seals. Similar methods were used to measure expansion behavior of glasses selected in Table 1 and the results are shown in Fig. 3. Again, the expansion behavior of YSZ is included in this data for comparison with the expansion of the glasses. Unlike the metals and YSZ, the glasses show a linear expansion up to a temperature ( $\mathrm{T}_{\mathrm{g}}$-glass transition temperature) followed by an increased expansion and then a decrease because of the softening of the glass at the glass softening temperature $\left(\mathrm{T}_{\mathrm{s}}\right)$. These expansion data of Fig. 3 were used to calculate coefficient of thermal expansion of glasses as well as the $T_{g}$ and $T_{s}$ values listed in Table 1. The values of $T_{g}$ and $T_{s}$ are very important for seal processing conditions. Typically, sealing temperatures are higher than the $\mathrm{T}_{\mathrm{s}}$ for creating conditions for good flow of the glasses because of the decreased viscosity. This is also important for self-healing behavior of promising glasses. These results show that the list of glasses selected offer a wide range of expansion, and glass transition/softening temperatures for making seals with YSZ and metals.

The video imaging technique described earlier was used to determine the crack-healing behavior of glasses and glass-ceramics listed in Table 1. In this approach a crack was created in the glass sample and then the sample was placed in a furnace with capabilities for observing the crack and crack healing behavior. The sample was heated to high temperatures between $25-1000^{\circ} \mathrm{C}$ at the constant rate and the video image of the crack was continuously taken. At a critical temperature, the crack started to heal as evident from the disappearing crack profile and this was noted as the start of the crack healing temperature. The temperature was increased further until the cracks completely disappeared from the view indicating an end of the crack healing as shown for glass 4 in Fig. 4. The range of temperature and the heating rate were used to calculate time-temperature profile required for crack healing. The results are listed as crack healing temperature $\left(T_{h}\right)$ in Table 1 for each of the glasses studied in this program.

Generally, glasses showing stability against devitrification/crystallization (Glasses 1, 3, 4) show crack-healing temperature above the glass softening temperature. In contrast, those glasses having more tendencies for crystallization (Glasses 2, 5, 6, 8) display slow crack healing that 


\section{DE-FC26-04NT42227 - Innovative Seals for Solid Oxide Fuel Cells (SOFC)}

occurs at temperatures much higher than the glass softening temperatures. In fact, Glass 8 that was made using Glass 1 and YSZ (70:30) showed unusual stability against healing and even at the crack-healing temperature of $1000^{\circ} \mathrm{C}$ the healing process was slow and incomplete.

The results indicated that generally $\mathrm{T}_{\mathrm{h}}$ is higher than the glass softening temperatures and it is much higher than $\mathrm{T}_{\mathrm{g}}$ in glasses showing tendencies for crystallization or in glass-ceramics. This may be one of the reasons that glasses with propensity for rapid crystallization may be less suitable for demonstrating self-healing behavior. Self-healing behavior of glass-7 could not be measured because suitable sample could not be obtained in time from UMR.

Seals were made using SS 430, Crofer, and Nickel metals, YSZ, Ni-anode-supported YSZ, and some of the glasses listed in Table 1. Nickel metal was also chosen for making seals as a model metal even though it has a larger expansion mismatch with both YSZ and glasses than Crofer and SS 430 to demonstrate that the self-healing glasses can be used to make hermetic seals even with metals with a significantly large expansion mismatch. In order to further select glasses appropriate for making seals, wetting experiments were performed in which tapes of glasses were placed on metals and YSZ to study the wetting behavior. Typical approach and results of the wetting behavior of glasses 1-4 with Crofer, SS 430, and Nickel metals are shown in Fig.5. These results show that glass 4 showed best wetting and flow behaviors on Crofer, SS 430, and Ni metals. As a consequence glass 4 was selected as one of the glasses for making seals. This glass also wets YSZ. The seals between Crofer, SS 430, and Ni and YSZ or anode-supported NiYSZ were made using glass 4 . The seal was then cooled to room temperature for leak testing. The seals showing hermetic behavior at $25^{\circ} \mathrm{C}$ were then used for making a joint with SS 304 housing for high-temperature leak testing.

A test fixture for leak testing seals was needed to assess performance of seals. Components for this test fixture included pressure transducer for monitoring pressure, readout indicator, valves for introducing gases or connecting to a vacuum system, sealing surfaces for sample placements, and a mechanical pumping system. These components were ordered, assembled, and leak tested. The assembled system, as shown in Fig. 6, was leak tight and maintained pressure for over several days as shown by data in Fig. 7. This system is interfaced with a computer for data acquisition (pressure Vs time) in a continuous manner using Labview software. The system was used for leak testing of seals both at room and elevated temperatures as described later. A special sample holder made of stainless steel (SS) was designed, built, and used for leak test at elevated temperatures.

\section{Leak Testing of Seals}

The seals fabricated using above approaches were tested for hermeticity at room temperature to insure that the processing parameters are correct. Hermetic seals were then tested further at elevated temperatures to demonstrate the effect of thermal cycles, self-healing behavior, and high temperatures on the leak rates.

The hermeticity of seals was determined by testing for leak via monitoring the pressure drop over a length of 1200 minutes (20 hours). The test methodology consisted of pressurizing the seal from one side to 900 Torr while maintaining the outside at atmospheric pressure of 740 Torr. This level of pressure drop was found to be more than enough to check for any type of 


\section{DE-FC26-04NT42227 - Innovative Seals for Solid Oxide Fuel Cells (SOFC)}

leaks. The inside pressure of the chamber was continuously monitored by a pressure transducer using a computer interface shown in Fig. 6. These approaches developed in this program were able to fabricate leak-tight seals between a variety of metals and YSZ using a glass. In addition, seals made using Nickel indicated that materials with a significant expansion mismatch could be hermetically sealed to YSZ using a glass. All the seals tested at room temperature survived a thermal cycle to room temperature as a part of the seal processing protocols.

\section{Demonstration of Self-Healing Seal}

The glass 4 was selected because of its stability against crystallization and expansion match between YSZ and some of the metals. In addition, it has a reasonable value of the glass softening behavior and self-healing response between $600-800^{\circ} \mathrm{C}$. To demonstrate that self-healing can occur it must be ascertained that the leak is due to cracks in the glass or at one of the interfaces such as between glass-metal or glass-YSZ. A leak at cracked YSZ is not a good candidate for demonstration of the self-healing behavior. Therefore, the methodology of leak testing at the unit cell seal (metal-glass-YSZ) level adopted in this program proved to be very useful in demonstrating the self-healing glass behavior. Leak test data for a Crofer-glass 4-YSZ seal in which the seal after fabrication was not leak tight because of leak at the glass-metal interface. This seal was heated to $800^{\circ} \mathrm{C}$ and held there for $2 \mathrm{~h}$ and then leak tested again and found to be leak-tight. This clearly shows the ability of the glass towards self-healing. These results clearly showed that a suitable glass can heal a leaking seal provided the glass has the desired characteristics for healing. Our approach of studying and monitoring the crack healing behavior using the video imaging approach proved to be a valuable tool for selecting and assessing the self healing behavior of the glasses.

\section{High-Temperature Testing of Seals and Associated Demonstration of Self-Healing}

The seal test station developed in the program was also used for leak testing at elevated temperatures. One of these seal assembly (Crofer-glass4-Ni/YSZ) was fabricated by joining Crofer to an anode-supported YSZ by glass 4 . This seal was hermetic at $25^{\circ} \mathrm{C}$ and then the seal was placed in a furnace for heating in a controlled manner to different temperatures and monitoring the leak rate. The results are summarized in Fig. 8. The seal assembly was heated at a rate of $5^{\circ} \mathrm{C} /$ minute to temperatures of $200^{\circ}, 400^{\circ}, 500^{\circ}, 600^{\circ}, 700^{\circ}$ and $750^{\circ} \mathrm{C}$. At each temperature, the seal was pressurized to a pressure of 780 Torr $(\Delta \mathrm{P}=40$ Torr $)$ and the leak was monitored in a manner similar to that described earlier. No pressure drop was seen for the test duration of $1 \mathrm{~h}$ at each of the temperatures. Subsequent to this, the seal was cooled to $500^{\circ} \mathrm{C}$ (below the glass transition temperature) and found to be hermetic at this stage as well. Then, the test was terminated because of lack of time available for the test. The results from this test indicated that seals fabricated in the program were hermetic at $25^{\circ} \mathrm{C}$ as well as at high temperatures. This methodology was pursued further to characterize self-healing seals development in this program.

Another seal \# 27 comprising of Crofer-glass4-YSZ was fabricated and tested between $25-800^{\circ} \mathrm{C}$ as shown in Fig. 9. This seal was tested at $25^{\circ}, 500^{\circ}, 700^{\circ}$, and $800^{\circ} \mathrm{C}$ for $1 \mathrm{hr}$ each during heating and again during cooling at $\Delta \mathrm{P}=50$ Torr (50 torr pressure drop). The seal remained hermetic for two cycles between $25^{\circ}-800^{\circ} \mathrm{C}$ but started leaking in the $3^{\text {rd }}$ cycle at $800^{\circ} \mathrm{C}$. A hold of this seal at $750^{\circ} \mathrm{C}$ for $1 \mathrm{hr}$. restored the hermetic behavior. The vary seal developed leak in the 


\section{DE-FC26-04NT42227 - Innovative Seals for Solid Oxide Fuel Cells (SOFC)}

$4^{\text {th }}$ cycle at $750^{\circ} \mathrm{C}$ and then it was held at $800^{\circ} \mathrm{C}$ for $1 \mathrm{hr}$. after the $4^{\text {th }}$ cycle, which again restored the hermetic behavior between 5-8 thermal cycles as shown in Fig. 9.

These results have clearly demonstrated that self-healing glass seals can be successfully engineered for a SOFC. This seal has shown excellent performance so far and have undergone over 2000 hours of testing at $800^{\circ} \mathrm{C}$ and over 235 thermal cycles between $25-800^{\circ} \mathrm{C}$ as described later.

\section{Task 2: Self-Healing Glass Development}

Glasses exhibiting self-healing behavior under SOFC operating conditions were further selected, developed, characterized, manufactured, and tested to demonstrate stability over an extended time periods through a variety of approaches.

\section{Experimental Methods/Approaches}

The long-term durability of the seals at high temperatures depends on the stability of the sealing materials such as glasses, YSZ, and metals. In addition, an understanding of the interactions of the sealing materials in contact with each other at high temperatures is also needed for making durable seals required for the SECA program. Toward these ends, experiments were performed to assess stability of the glasses ( glasses 1-7 shown in Table 1) against crystallization at hightemperatures $\left(800^{\circ} \mathrm{C}\right)$. The progress of crystallization was monitored by $\mathrm{x}$-ray diffraction. Thermal expansion behaviors of the annealed samples were measured to assess the role of the crystallization on changes in the glass properties $\left(\mathrm{T}_{\mathrm{g}}, \mathrm{T}_{\mathrm{s}}\right)$ important for making and retaining seals. In addition, reactivity of the glasses against metals and YSZ were assessed by annealing the metal-glass and glass-YSZ couples at $800^{\circ} \mathrm{C}$ for $200-500 \mathrm{hrs}$ and the cross-sections of the annealed samples were examined to determine stability against reactions. The most promising glass was then used in making seals and for assessing long-term performance of the seals through seal testing between $25-800^{\circ} \mathrm{C}$. The results of these investigations are described below.

\section{Results and Discussion}

\section{Thermal Stability of the Seal Materials}

Sintered glass samples were progressively annealed between $10-500$ hours at $800^{\circ} \mathrm{C}$ and stability monitored after each annealing interval. Samples were annealed in air and $\mathrm{Ar}-4 \% \mathrm{H}_{2}$ up to 500 hrs. The glasses 1-3 start crystallizing in $10 \mathrm{hrs,} \mathrm{and} \mathrm{glass} 4$ in 75-100, glass 5 from the start (glass-ceramics), and glass 6 in 50 hrs. It should be noted that samples of glasses 6 and 7 used in this study were from solid plates supplied by UMR whereas other samples were used in the powder form. Glass powders are more prone to crystallization than the solid pieces but in actual practice glass powders are more useful in processing to make seals. We could not study glasses 6 and 7 against crystallization in powder form because of the unavailability of powders. All of these glasses were also annealed in reducing gas $\left(\mathrm{Ar}-4 \% \mathrm{H}_{2}\right)$ for assessing their stability in a reducing environment. The results for most glasses were similar to those in the oxidizing environment except that glass 4 was slightly more stable against crystallization in the reducing gas (100 hrs Vs $75 \mathrm{hrs}$ ) than in the oxidizing conditions. These results suggest that glass 4 is most suited for self-healing development. 


\section{DE-FC26-04NT42227 - Innovative Seals for Solid Oxide Fuel Cells (SOFC)}

\section{Effect of Thermal Annealing on Expansion Behavior}

The effect of thermal exposure on the expansion behavior of glass- 4 was measured. It shows an insignificant change in the glass transition and softening temperatures and expansion behaviors of the glass even after annealing for $500 \mathrm{hrs}$ indicating that although crystallization is detected after 100 hrs. of thermal exposure of this glass, the extent of crystallization is small. This is consistent with long-term durability of the seals as described later.

\section{Effect of Thermal Annealing on Glass-Metal and Glass-YSZ Reactions}

The experiments were performed to assess stability of the glasses against reactions with metals and YSZ at high-temperatures $\left(800^{\circ} \mathrm{C}\right)$. Samples of glasses 3, 4, and 5 in contact with Crofer and YSZ were prepared and annealed at $800^{\circ} \mathrm{C}$ for 200 hours. The SEM was used to examine the interface for any possible reactions. The results are shown in Fig. 11 for glasses 3-5 in contact with Crofer indicating insignificant changes/reactions at the interface. The same glasses in contact with YSZ were also exposed at $800^{\circ} \mathrm{C}$ for 200 hours and the results in Fig. 12 also show insignificant changes or reactions.

\section{Electrical Properties of the Sealing Glasses}

The baseline electrical properties of glasses 3-5 were measured over a range of frequencies between $10^{-4}$ to $10^{6} \mathrm{~Hz}$ and between $25^{\circ}-600^{\circ} \mathrm{C}$ The low frequency response is useful for SOFC as near DC resistance and high frequency response gives information on the capacitive component of the sample as well as any interface resistance because of the metal electrode-glass interface. A platinum thin film electrode was used in all these measurements. The results are summarized in Table 2.

Glasses 3 and 4 are mostly amorphous and glass 5 is a glass-ceramic. All the samples show very high resistance at low frequencies and should remain insulating as a sealant in SOFC. Measurements of the electrical properties of these glasses along with the toughened glasses at even higher temperatures will be reported in the future to make sure that these glasses remain insulating near the SOFC operating temperatures of $800^{\circ} \mathrm{C}$.

\section{Effect of Thermal Cycles and High-Temperature Exposures on Seal Durability}

The stability of glass 4 at $800^{\circ} \mathrm{C} / 500 \mathrm{~h}$ in air, $\mathrm{Ar}-4 \% \mathrm{H}_{2}$, slow crystallization behavior, insignificant changes in expansion upon annealing, and lack of reactions with Crofer and YSZ prompted us to study the seal performance over an extended time period. The seal \#27 comprised of Crofer-glass4-YSZ, which had displayed self-healing behavior in Fig. 9 was selected for this study. As mentioned this seal has been running since March 2005 and has undergone a variety of seal testing. This included extended leak testing at $800^{\circ} \mathrm{C}$, repeated thermal cycling between $25^{\circ}$ $800^{\circ} \mathrm{C}$, testing in $\mathrm{Ar}-4 \% \mathrm{H}_{2}, \mathrm{Ar}-4 \% \mathrm{H}_{2}-6 \% \mathrm{H}_{2} \mathrm{O}$, as well as in dual gases comprising of $\mathrm{Ar}-4 \% \mathrm{H}_{2}-$ $6 \% \mathrm{H}_{2} \mathrm{O}$ on one side and air on the other side of the seal/YSZ membrane. The tests in reducing environment and dual atmosphere were done because of the interest of one of the industrial members of the SECA team. A brief description of these results is given below.

A seal \#27 was tested at $25^{\circ}, 500^{\circ}, 800^{\circ} \mathrm{C}$ for one hour upon heating and then upon cooling to $500^{\circ} \mathrm{C}$ and $25^{\circ} \mathrm{C}$. A hermetic behavior at each temperature is demonstrated. This vary seal was tested for leak at $800^{\circ} \mathrm{C}$ continuously for an extended time of 50 hours in each of the cycles 


\section{DE-FC26-04NT42227 - Innovative Seals for Solid Oxide Fuel Cells (SOFC)}

between 116 to 121 and remained hermetic as evident from Fig. 28 indicating durability of the seal. Figure 13 shows data of leak testing between 122 and 148 thermal cycles at $25^{\circ}$ and $800^{\circ} \mathrm{C}$. A small leak was developed in cycle 137 at $25^{\circ} \mathrm{C}$ as evident from the slope of the data as a function of time. However, the seal was healed in the $139^{\text {th }}$ cycle and remained hermetic thereafter to cycle \# 149. The effect of higher-pressure drops between 10-30 Torr on the leak behavior of the seal is demonstrated for each of the thermal cycles between 186-195. The seal remained hermetic at both $25^{\circ}$ and $800^{\circ} \mathrm{C}$ for tests lasting for 2 hours. The leak testing of the seal in $\mathrm{Ar}-4 \% \mathrm{H}_{2}$ and the results show hermetic behavior in fuel environment as well. Seal testing in Ar- $4 \% \mathrm{H}_{2}-6 \% \mathrm{H}_{2} \mathrm{O}$ also demonstrated hermetic response as evident from Fig. 14. The seal has also undergone $>300$ hours of testing in dual gas environment and remains hermetic. These included more recent tests for 404 hours and 22 thermal cycles in $\mathrm{Ar}-4 \% \mathrm{H}_{2}$, and 300 hours and 14 thermal cycles in $\mathrm{Ar}-4 \% \mathrm{H}_{2}-6 \% \mathrm{H}_{2} \mathrm{O}$ and $>300$ hours and 10 thermal cycles in dual environment consisting of moist fuel on one side and air on the other side.

We believe the methodology for seal testing developed in this program may be better suited for developing robust seals because the current method of placing the sealants between Inconel housings under pressure is not prototypic because neither the Inconel nor the sealants are configured realistically to an operating SOFC. Consequently, the leak test results may not be pertinent to an operating SOFC or for developing seal systems/materials useful for the SOFC. In SOFCs, the electrolyte is sealed to a metallic support using a glass or other possible sealants and the supporting metal is welded/joined to the rest of the SOFC metallic structures. Consequently, seal tests should be performed on a seal unit comprised of YSZ-glass-Metal, which should be joined to a metal of a leak test stand. This is exactly what was done in this program.

\section{Task 3: Toughening of Glass}

Sealing glasses can be strengthened and toughened by a reinforcement phase. Toward this goal, promising sealing glasses are being reinforced with fibers/whiskers, manufactured, and tested to characterize properties.

\section{Experimental Methods/Approaches}

A reinforcement phase is required to toughen sealing glasses as a part of this activity. The reinforcing phase should be oxidation resistant at $800^{\circ} \mathrm{C}$, strong, and have expansion behavior close to the sealing glass. This limits the possible material choices for the reinforcement phase. Some of the possible materials are alumina, zirconia, and related phases because of the excellent oxidation resistance and expansion characteristics. However, to achieve toughening and strengthening of the glass by these fibers require a weak fiber-matrix interface. This may not be possible in an oxide (fiber)-glass system because of the expected strong bonding. Consequently, an interface coating on fiber may be required or possible selection of the non-oxide fibers may be necessary. This further limits the choices of available fibers, but it is being explored.

\section{Results and Discussion}

\section{Selection of the Reinforcement Phase and Processing}

Initial experiments have been done to use a commercial Nextel-610 oxide fiber and woven fabrics from it. This is expected to have good expansion match with the glass 4 for initial 


\section{DE-FC26-04NT42227 - Innovative Seals for Solid Oxide Fuel Cells (SOFC)}

investigation. Both chopped fibers and continuous fibers are being considered. Initial experiments were done to infiltrate glass 4 into a preform made of Nextel 610, and whiskers of the same fibers are obtained for use in these experiments as well. Samples of the reinforced glass- 4 by Nextel 610 fibers were fabricated. The electrical properties of the reinforced glasses are measured to compare with the electrical properties of the baseline data reported in Table 2. The baseline electrical properties of glasses were measured over a range of frequencies between $10^{-4}$ to $10^{6} \mathrm{~Hz}$. The low frequency response is useful for SOFC as near DC resistance and high frequency response gives information on the capacitive component of the sample as well as any interface resistance because of the metal electrode-glass interface. A platinum thin film electrode was used in all these measurements. The results are summarized in Table 2. Glasses 3 and 4 are mostly amorphous and glass 5 is a glass-ceramic. All the samples show very high resistance at low frequencies and should remain insulating as a sealant in SOFC. Measurements of the electrical properties of these glasses along with the toughened glasses at even higher temperatures will be reported in the future to make sure that these glasses remain insulating near the SOFC operating temperatures of $800^{\circ} \mathrm{C}$. Thermophysical and mechanical properties of the glasses will be determined and promising combination of the reinforced glasses will be evaluated through leak tests.

\section{Task 4: Survey of Commercial Glasses}

Commercial glasses were surveyed for their suitability for making seals useful in a SOFC. Some of the selection criteria included composition, CTE, softening point and crystallization behavior. Previously collected data from Sandia National Laboratory, the University of Missouri - Rolla, and PNNL were also integrated into this database. Commercial glasses with a promising combination of properties will be selected and further tested for thermomechanical properties and chemical stability at high temperatures.

\section{Task 5: Project Management/Reporting}

The technical and administrative management for all aspects of the research project in accordance with the Cooperative Agreement were provided.

\section{Conclusions}

All the objectives of Phase 1 program have either been met as follows.

(1) A number of glasses were selected for demonstration of self-healing behavior and potential for making seals that display self-healing response. These glasses were obtained and their structure, thermophysical properties (expansion), densification behavior, and wetting behavior with YSZ electrolyte, Crofer, SS 430, and Nickel metals were determined for suitability of making seals. Based on these characterizations the more promising glasses were selected for making seals.

(2) Sintered samples of glasses and YSZ were fabricated for the program. This consisted of developing procedures for tape casting of glasses and YSZ, sintering procedures to make dense YSZ and glasses, and preparation of metals appropriate for making seals 


\section{DE-FC26-04NT42227 - Innovative Seals for Solid Oxide Fuel Cells (SOFC)}

(3) A new methodology based on video imaging of cracks were applied to characterize selfhealing behavior of all the selected glasses and glass-ceramics as a function of temperature and time. The analysis of the crack-healing data was used to arrive at the self-healing temperaturetime history for use in self-healing of the glass seals. This also provided information on the suitability of the glasses for providing self-healing capability. Generally, glass-ceramics showed slower self-healing kinetics than the glassy state but the exact kinetics was dependent on the specific glass or glass-ceramics.

(4) A seal test system was designed and built for testing seals both at room and elevated temperatures up to $1200^{\circ} \mathrm{C}$. The system has facilities for continuously monitoring pressure as a function of time from which leak rates can be assessed. This facility was extensively used in developing hermetic seals that display self-healing behavior.

(5) Seals incorporating some of the more promising glasses were fabricated. Towards this, wetting behaviors of glasses with metals and YSZ were studied and promising glasses were further down-selected for fabricating seals. Extensive efforts were expended on developing seals that show hermetic response both at room and elevated temperatures. Effect of up to 9 thermal cycles between 25 and $800^{\circ} \mathrm{C}$ on hermeticity of the seals was demonstrated. Self-healing behaviors of the leaking seals were demonstrated by heating the seals to sealing temperatures and then measuring the leak behavior, which demonstrated recovery of the hermeticity after selfhealing treatments. Seals were also tested at higher temperatures between $25-800^{\circ} \mathrm{C}$ and displayed hermetic behavior at each of the temperatures.

(6) Thermal stability of the sealing glasses were determined by annealing glasses alone and glass-metal, and glass-YSZ couples at $800^{\circ} \mathrm{C}$ for times up to 500 hours. The thermophysical and thermochemical stability of the glasses against reaction and crystallization were determined. The results displayed insignificant changes in properties from the as-fabricated state indicating stability of the sealing material systems. Further testing of the seals at high temperatures is continuing to collect more data on the effect of thermal transient on the hermeticity of the seals.

(7) Extensive testing of the seals comprising of Crofer-Glass-YSZ at high temperatures of $800^{\circ} \mathrm{C}$ and under thermal cycling between $25^{\circ}$ and $800^{\circ} \mathrm{C}$ was performed. This included demonstration of self healing behavior, short-term and extended-time leak testing at each of the temperatures, thermal cycling, and the effect of test atmosphere (including dual atmosphere) on the leak performance. The seal has accumulated over 2000 hours of testing at $800^{\circ} \mathrm{C}$ and has undergone over 236 thermal cycles and remains hermetic. These results provide encouraging results on self-healing glass seals for further development in Phase II of the proposed program.

\section{Progress from Phase II}

The goal of this phase is to select glasses that show self-healing behavior and long-term stability in SOFC environments. Some of the glasses from Phase I will be used and modified by changes to their composition to achieve stability for long time in SOFC conditions. The compositional modifications will be done to achieve optimum expansion behavior in contact with Crofer and 


\section{DE-FC26-04NT42227 - Innovative Seals for Solid Oxide Fuel Cells (SOFC)}

Ni-YSZ, glass transition and softening temperatures over a range of temperatures between 600$800^{\circ} \mathrm{C}$ without adversely affecting stability. Fillers will also be tried to achieve some of these goals. The stability of the glasses selected above will be determined by annealing glass samples in air and simulated fuel $\left(\mathrm{Ar}-4 \% \mathrm{H}_{2}-6 \% \mathrm{H}_{2} \mathrm{O}\right)$ environments at $800^{\circ} \mathrm{C}$ for up to 1000 hours. The weight change will be monitored to see any loss, which will be related to changes in the composition of the glass by techniques such as EDAX, SIMS, or ESCA.

\section{Task 1: Self-Healing Sealing Glass Development}

The viscosity of the glass sample was determined from the DSC data reported in Phase I program. DSC run gives the values of start and end temperatures of glass transition. These values were plugged into the Moyniham equation in order to get the temperature dependent viscosity values for the glass. The equation used to calculate the glass viscosity at various temperatures is given as,

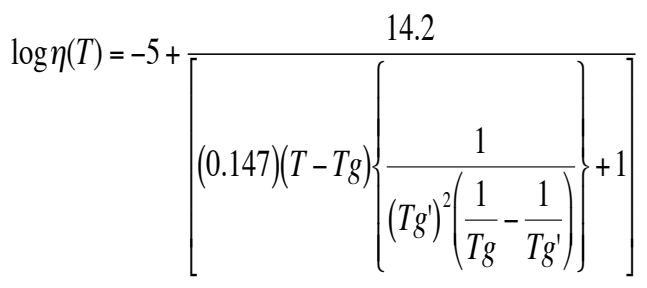

where, $\mathrm{Tg}$ is glass transition start temperature in Kelvin and Tg' glass transition end temperature in Kelvin. The calculated viscosity of the glass is shown in Fig. 15 over a range of temperature using $530^{\circ}$ and $595^{\circ} \mathrm{C}$ of the transition temperatures. A viscosity of $10^{5} \mathrm{~Pa} . \mathrm{s}$ is obtained at $800^{\circ} \mathrm{C}$ of the $\mathrm{SOFC}$ operating temperature.

Figure 16 (a) shows the weight loss data for a self-healing glass annealed at $800^{\circ} \mathrm{C}$ in humid fuel environment consisting of $\mathrm{Ar}-4 \% \mathrm{H}_{2}-6 \% \mathrm{H}_{2} \mathrm{O}$ over a time period of 500 hours. This set of data was collected at 100-hour intervals by stopping the experiment and cooling the sample to room temperature. This data is replotted in Fig. 16 (b) as weight loss per $\mathrm{cm}^{2} \mathrm{Vs}$ time. Based on the preliminary data on weight loss, a calculated total loss in weight of the glass in 40,000 hours based on the extrapolation of data in (a) gives $0.533 \%$ weight loss, which is insignificant.

Glass samples alone and those containing 5\% (wt) YSZ powder were annealed in air atmosphere at $800^{\circ} \mathrm{C}$ over a range of times up to 1500 hours to determine long-term stability, crystallization behavior. Figure 17 shows an example of the effect of annealing in air on the stability of the glass. The x-ray diffraction patterns from the glass-5\% YSZ taken at different times of annealing are shown in Fig. 17, which indicates that the glass did not show any evidence of crystallization because of the $5 \% \mathrm{YSZ}$ in it over the annealing times of 1500 hours at $800^{\circ} \mathrm{C}$ in air.

Creep behavior of the sealing glass is important for assessing flow behavior of the self-healing sealing glass subjected to stack loads. The creep behavior of the glass samples were measured near the glass softening temperatures in a flexure mode at an applied load of $10 \mathrm{~N}$. Figure 18 shows the creep data over a range of temperatures. These data were used to calculate viscosity of the glass over a range of temperatures. The results can be fitted to the following equation. 


\section{DE-FC26-04NT42227 - Innovative Seals for Solid Oxide Fuel Cells (SOFC)}

$$
y=15.358 x-5.4587
$$

where $y=\log \left(\right.$ viscosity in Pa.s) and $\mathrm{x}=10^{3} / \mathrm{T}$ (temperature in $\left.\mathrm{K}\right)$. The values of viscosity determined over a range of temperatures also gave an activation energy value of $125 \mathrm{~kJ} / \mathrm{mole}$. These results were provided to PNNL and used in collaborative study on modeling of the thermomechanical response of seals in a cell stack. These results for our self-healing glass as well as those for G18-glass from PNNL were communicated.

\section{Task 2: Toughened Glass}

Glass containing reinforcing fiber will be prepared and sintered to make dense composites. The mechanical properties of these samples will be determined to assess any toughening and strengthening. The expansion behavior of the sample will also be measured to find out the affect of fiber addition on the thermo-mechanical behavior of the reinforced glass.

This task was discontinued because of the redirected program.

\section{Task 3: Seal Testing of Toughened Glass}

A seal made using Crofer and glass with fibers has been tested by annealing the seal at $800^{\circ} \mathrm{C}$ for different length of times and then measuring the leak rates at room temperature. This seal has accumulated 1000 hours of exposure at $800{ }^{\circ} \mathrm{C}$ and remained hermetic.

\section{This task was discontinued because of the redirected program.}

\section{New Tasks of the Redirected Program:}

\section{Task 1: Determine Compatibility of Self-Healing Glass with 441 Stainless Steel}

Samples of 441 steel, uncoated and coated with CoMn-spinel were obtained from PNNL through Jeff Stevenson for testing of compatibility with the self-healing glass. The samples had one side coated with spinel and the other side was uncoated. Glass was placed on the uncoated and coated samples and these were annealed in air at $800^{\circ} \mathrm{C}$ for 1000 hours. Weight of the sample was also monitored so that the results on chemical compatibility can be related to the weight loss data. Initial tests indicated that chromia from 441 came out and since then another set of spinel-coated samples were obtained from PNNL and these were also annealed in contact with our glass to assess compatibility. After the test all these samples were cut and polished for examination by SEM and EDAX to determine chemical compatibility. Some of the findings of these studies are summarized below.

Figure 19 shows a cross-section of glass in contact with $441 \mathrm{SS}$ after annealing at $800^{\circ} \mathrm{C}$ for 1000 hours. The glass-441SS interface has a region enriched in $\mathrm{Cr}$ and $\mathrm{O}$ indicating formation of the chromia scale on $441 \mathrm{SS}$ as expected. No Co-Mn spinel coating is evident in this data indicating that the $441 \mathrm{SS}$ used in this study was not coated. There is a darker region between the chromia scale and the glass in which there is an enhanced Si level in comparison to the glass along with a slight increase in the $\mathrm{O}$ level. There is no evidence of Fe or other elemental diffusion from the $441 \mathrm{SS}$ into the glass. The glass also shows chemical and mechanical stability against Chromia dissolution from the oxidized $441 \mathrm{SS}$. This is important because other glass sealing materials have shown propensity toward reaction with chromia scale and possible 


\section{DE-FC26-04NT42227 - Innovative Seals for Solid Oxide Fuel Cells (SOFC)}

delamination resulting from it. A slight enrichment of the glass by $\mathrm{Si}$ and $\mathrm{O}$ near the chromia scale is interesting and will require further studies.

Figure 20 shows a cross-section of glass in contact with CoMn spinel-coated 441 SS after annealing in air for 1000 hours. The glass-metal interface has 3 regions. A chromia layer next to the 441SS followed by a CoMn spinel layer of coating. After this there is a thicker region in contact with the glass. This region is formed because of the dissolution of CoMn spinel into the glass and has a small amount of Co and Mn along with Si from the glass. Higher magnification of this region shows particles of CoMn spinel dispersed into the glass with larger particles near the CoMn spinel coating (left) and smaller particles neat the glass (right) indicating the different degree of dissolution of CoMn spinel into the glass. The spinel coating is still there on the 441SS but may get dissolved when samples are annealed for longer times than the 100 hours. These results indicated that CoMn spinel coating may not be stable in contact with this glass but appears to be adherent. The presence of chromia coating on 441 SS may have formed upon oxidation of the 441SS during annealing indicating that the CoMn spinel coating may not be protective against oxidation unless this coating was formed during CoMn spinel coating process.

Figure 21 shows SEM and EDAX results on compatibility of 441 SS with aluminized coating and glass sample annealed for 1000 hours at $800^{\circ} \mathrm{C}$. Again, chromia scale is formed on the $441 \mathrm{SS}$ so the aluminized coating was not effective in preventing the chromia formation. The Al line scans also suggests insignificant $\mathrm{Al}$ in the aluminized $441 \mathrm{SS}$. The $\mathrm{Si}$ and $\mathrm{O}$ are also enhanced near the chromia-glass interface in the region that appears a bit darker than the glass. These results again support the stability of the chromia scale against glass in terms of the chemical and mechanical properties. The chromia scale appears adherent to the glass and 441SS.

\section{Task 2: Electrical Property of Self-Healing Glass in Contact with Coated 441 SS}

In addition, electrical resistivity of the self-healing glass under DC applied electric field was measured between $25-800^{\circ} \mathrm{C}$. These measurements were done at an applied voltage of 1 volt, which is typical of a cell voltage in a SOFC. Figure 22 shows measured resistivity between $25-800^{\circ} \mathrm{C}$. The data show very high resistivity values in the range of $10^{9} \mathrm{ohm}-\mathrm{cm}$ between $25-$ $600^{\circ} \mathrm{C}$ and then it decreases at higher temperatures and attains a value of $10^{6} \mathrm{ohm}-\mathrm{cm}$ at $800^{\circ} \mathrm{C}$. This value at $800^{\circ} \mathrm{C}$ is quite high indicating insulating characteristics for the glass. This is reasonable because the glass is ionically bonded and conduction is via movement of ions. In the presence of a DC field there is an initial high current, which subsides to a steady low value because of the ionic polarization. This leads to an insulating behavior for the glass exposed to DC field as observed in our measurements.

Glass samples sandwiched between two spinel-coated 441 SS were prepared for measurement of electrical resistance at $800^{\circ} \mathrm{C}$ in order to determine suitability of the glass in contact with spinel-coated $441 \mathrm{SS}$ as an interconnect. The purpose of this type of test is to assess the durability of the glass against dissolution of constituents form spinel containing Co and Mn oxides, which can affect the electrical resistance of the glass. The sandwich structure with glass in between the coated-441 SS was exposed at $800^{\circ} \mathrm{C}$ in air for 1000 hours under a DC voltage of $1 \mathrm{~V}$ to simulate interconnect behavior of a SOFC. The electrical measurements consisted of 


\section{DE-FC26-04NT42227 - Innovative Seals for Solid Oxide Fuel Cells (SOFC)}

current-voltage measurements as a function of time at temperatures between $500-800^{\circ} \mathrm{C}$. The changes in resistance were used to calculate resistivity and to assess stability of the glass for suitability as an insulating medium between interconnects materials.

Figure 22 shows the data on resistivity of the glass in contact with CoMn spinel-coated 441 $\mathrm{SS}$ as a function of time. The results show resistivity values between $10^{4}-10^{5} \mathrm{ohm}-\mathrm{cm}$. The increase in resistivity with time under a DC field is expected because the glass is an ionic conductor and experiences polarization, which reduces the ionic charge carriers with time and hence increases the resistance. Nonetheless, the values of resistivity indicate essentially insulating glass characteristics. The data on the glass tested alone shows higher resistivity possibly because of the dissolution of CoMn spinel coating into the glass. This is evident from bluish coloration of the glass after electrical test in which electrodes were CoMn spinel-coated 441 SS. Figure 23 shows the pictures of samples after the electrical test in which more bluish coloration is seen near the positive electrode than the negative electrode. These results indicate that CoMn-spinel coating may dissolve into the glass under an applied DC field and this is expected to lower electrical resistivity of the glass. Nonetheless, the electrical resistivity of the glass is still fairly high after 1000 hours of the test duration. But, what will happen over a much extended time period will require further studies.

A similar experiment was performed in which aluminized 441 SS was used. The sandwich structure with glass in between the aluminized-441 SS was exposed at $800^{\circ} \mathrm{C}$ in air for 1000 hours under a DC voltage of $1 \mathrm{~V}$ to simulate interconnect behavior of a SOFC. Figure 24 shows the data on resistivity of the glass in contact with CoMn spinel-coated 441 SS (previously reported) along with the data on aluminized 441SS as a function of time. The results show resistivity values between $10^{4}-10^{5} \mathrm{ohm}-\mathrm{cm}$. The values of resistivity indicate essentially insulating glass characteristics. The data on the glass tested alone shows higher resistivity because of the dissolution of CoMn spinel coating into the glass. This is evident from bluish coloration of the glass after electrical test in which electrodes were CoMn spinel-coated 441 SS. The data on aluminized 441 SS is in between the glass and Co-Mn Coated sample because the aluminized coating is not yet sufficient to protect the 441SS. These results indicated that further work is needed to optimize the coatings so that they are protective. Aluminized coating may provide more promise than the Co-Mn Spinel coating. Nonetheless, the electrical resistivity of the glass is still fairly high after 1000 hours of the test duration. But, what will happen over a much extended time period will require further studies.

\section{Task 3: Fabricate Glass Samples for Seal Test at NETL}

After extensive discussions and interactions with NETL personnel, Randy Gemmen and Chis Johnson, a plan to test self-healing glasses in a cell-rig at NETL has been initiated. Two samples of the glass in the form of washers were prepared at UC and delivered to Randy Gemmen at NETL. These samples will be used as seals in the cell test stand at NETL and the performance of the cell will be monitored. A similar cell without the glass seal will also be tested for providing the baseline data for comparison to the cell with glass seal. The results from these tests will provide future directions for additional testing to assess the behavior of self-healing glasses for applications in SOFCs useful for the SECA program. 


\section{DE-FC26-04NT42227 - Innovative Seals for Solid Oxide Fuel Cells (SOFC)}

\section{Task 4: Fabrication of $2 \mathrm{~kg}$ Glass Sample}

After extensive discussions with the SECA management team, a decision was made to fabricate $2 \mathrm{~kg}$ batch of our glass sample and deliver to ORNL It was processed and delivered to ORNL on August 27, 2008.

\section{Conclusions from Phase II Program:}

The primary focus of the project during this reporting period has been to continue work on Phase II of the program. The major goal of this phase is to determine longer-term stability of the selfhealing seals developed in Phase-I of the program. The following are some of the important findings of the program. There has been a redirection of efforts.

(1) Developed self-healing glasses for making seals for SOFC. The seals were tested for leak at $800^{\circ} \mathrm{C}$ and demonstrated self-healing ability for tests performed for 3000 hours and 300 thermal cycles in a variety of test environments typical of a SOFC. Self-healing glasses have shown stability against crystallization in seal tests for 3000 hours, and in thermal annealing tests in air at $800^{\circ} \mathrm{C}$ for 1700 hours.

(2) In situ X-ray diffraction of glasses at temperatures between $25-800^{\circ} \mathrm{C}$ displayed no crystal phases in tests performed at NETL.

(3) The weight loss experiments performed in moist fuel environment at $800^{\circ} \mathrm{C}$ for 500 hours displayed insignificant weight loss. A weight loss of $0.53 \%$ over 40,000 hours is calculated from extrapolated data. Analyses of samples after annealing by XPS depth profiling indicated little change in elemental depth profile after annealing.

(4) DC electrical resistivity of the self-healing glass between $25-800^{\circ} \mathrm{C}$ is measured with a value of $0.6 \times 10^{6} \mathrm{Ohm}-\mathrm{cm}$ at $800^{\circ} \mathrm{C}$.

(5) Creep tests were performed on a self-healing glass to determine glass flow behavior and the data were used to calculate glass viscosity useful in modeling response of the sealing glass in a SOFC stack.

(6) Initiated redirected program and measured compatibility and electrical properties of glass in contact with coated $441 \mathrm{SS}$.

(7) Fabricated $2 \mathrm{~kg}$ of glass and shipped to ORNL on August 27, 2009.

\section{Acknowledgments}

The author is thankful to S. Parihar, N. Govindraju, S. Singh, and D. Das for help on the experimental work. This project was partly supported by University of Cincinnati and US Department of Energy-SECA program through grant No. DE-FC26-04NT42227. The guidance of Travis Shultz and Mani Manivannan, Project Managers-Fuel Cells (DOE-NETL) is very much appreciated. Useful discussions with Don Collins, Wayne Surdoval, Lane Wilson, and 


\section{DE-FC26-04NT42227 - Innovative Seals for Solid Oxide Fuel Cells (SOFC)}

Mark Williams of DOE-NETL, Prabhakar Singh, Matt Chou, and Jeff Stevenson of PNNL, N. Minh of GE-Energy, Diane England of Delphi, and Pinakin Patel of FuelCell Energy are also appreciated. Some of the electrolyte samples used in this study were kindly supplied by Anil Virkar of University of Utah, S. Elangovan of Ceramatec, and Matt Chou of PNNL.

\section{References}

1. Wayne Surdoval, “Fossil Energy Fuel Cell Program,” SECA Workshop/Meeting, July 8-9, Sandia Labs. (2003).

2. Prabhakar Singh, "Sold Oxide Fuel Cell Power Generation: Technology Status," SECA Workshop/Meeting, July 8-9, Sandia Labs. (2003).

3. R.N. Singh, "High Temperature Seals for Solid Oxide Fuel cells," Ceram. Eng. Sci. Proc. (2004).

4. R.N. Singh and S. Parihar, " Layered Composite Seals for Solid Oxide Fuel Cells," Ceram. Eng. Sci. Proc. (2004).

5. R.N. Singh, " High Temperature Seals for Solid Oxide Fuel Cells (SOFC)," ASM Conf. Proceedings (2004).

5. G. Meier, "Fundamental Study of the Durability of Materials for Interconnct in Solid Oxide Fuel Cells," SECA Core Technology Program Review, October 1 (2003), Albany, NY.

6. K. S. Weil, J.S. Hardy, and J.Y. Kim, " Use of a Novel Ceramic-Metal Braze for Joining in High Temperature Electrochemical Devices," The Joining of Advanced and Specialty Materials, V, ASM (2003).

7. C. Lewinsohn, S. Quist, and S. Elangovan, “ Novel Materials for Obtaining Compliant, High Temperature Seals for Solid Oxide Fuel Cells," SECA Core Technology Program Review, October 1 (2003), Albany, NY.

8. R. Loehman, “Development of High Performance Seals for Solid Oxide Fuel Cells," SECA Core Technology Program Review, October 1 (2003), Albany, NY.

9. Y.S. Chou, " Compressive Seals Development," SECA Core Technology Program Review, October 1 (2003), Albany, NY.

10. Y.S. Chou, J.W. Stevenson, and L.A. Chick, “ Ultra Low Leak Rate of Hybrid Compressive Mica Seals for SOFC,” J. Power Source, 112, 130 (2002).

11. Y.S. Chou and J.W. Stevenson, " Mid-Term Stability of Novel Mica-Based Compressive Seals for SOFC," J. Power Source, 115, 274 (2003).

12. S. Tanaguchi, M. Kadowaki, T. Yasuo, Y. Akiyamu, Y. Miyaki and K. Nishio, “ Improvement of Thermal Cycle Characteristics of a Planar-Type SOFC by Using Ceramic Fiber as a Sealing Material," J. Power Sources, 90, 163 (2000).

13. R.K. Brow and D.S. Reis, Designing Sealing Glasses for Solid Oxide Fuel Cells, ASM Materials Solutions Conference and Exposition, October 18-20, 2004, Columbus, OH.

14. I.W. Donald, " Review: Preparation, Properties, and Chemistry of Glass and Glass-Ceramicto Metal Seals and Coatings," J. Mater. Sci., 28, 2841 (1993).

15. R.N.Singh and J.L.Routbort, " Fracture and Crack Healing in (U,Pu)C", J. Am. Ceram. Soc., 62,128 (1979). 
DE-FC26-04NT42227 - Innovative Seals for Solid Oxide Fuel Cells (SOFC)

Table 1: Glass properties and self-healing behavior.

\begin{tabular}{|c|c|c|c|c|c|c|}
\hline Glass & Type & \multirow{2}{*}{$\begin{array}{c}\text { Density } \\
\end{array}$} & & \multicolumn{4}{|c|}{ Glass Properties } \\
\cline { 4 - 7 } & & $\mathbf{g} / \mathbf{c c})$ & $\mathbf{\alpha}$ & $\mathbf{T}_{\mathbf{g}}$ & $\mathbf{T}_{\mathbf{s}}$ & $\mathbf{T}_{\mathbf{h}}$ \\
\hline Glass-1 & Silicate Glass & 2.5 & $9.5-11$ & 470 & 560 & $530-550$ \\
\hline Glass-2 & $\begin{array}{c}\text { Silicate/Glass- } \\
\text { ceramics }\end{array}$ & 2.8 & $10-11$ & 610 & 710 & $680-805$ \\
\hline Glass-3 & Silicate Glass & 2.8 & $9.5-11$ & 620 & 720 & $630-670$ \\
\hline Glass-4 & Silicate Glass & 2.4 & $10.5-13$ & 520 & 590 & $540-575$ \\
\hline Glass-5 & $\begin{array}{c}\text { Ba-Al-B-La } \\
\text { Silicate/Glass- } \\
\text { Ceramics }\end{array}$ & 3.9 & $10-11$ & 600 & 720 & $750-900$ \\
\hline Glass-6* & $\begin{array}{c}\text { Sr-Ca-B-Zn-Ti- } \\
\text { Silicate Glass- } \\
\text { Ceramics }\end{array}$ & 3.6 & 9.5 & 700 & 740 & $720-795$ \\
\hline Glass-7* & $\begin{array}{c}\text { Sr-Ca-B-Silicate } \\
\text { Glass }\end{array}$ & 3.4 & 10.9 & 745 & 760 & TBD \\
\hline Glass-8 & $\begin{array}{c}\text { Glass 1+YSZ } \\
\text { (70:30 wt\%) } \\
\text { Glass-ceramics }\end{array}$ & 2.7 & $9.5-10.3$ & 680 & $>850$ & $775-$ \\
\hline Glass-9 & $\begin{array}{c}\text { Glass 1+YSZ } \\
\text { (70:50 wt\%) } \\
\text { Glass-ceramics }\end{array}$ & 2.95 & $9.3-10$ & NA & NA & - \\
\hline
\end{tabular}

$\underline{\alpha}$ Coefficient of thermal expansion $\left(\mathrm{ppm} /{ }^{\circ} \mathrm{C}\right) ; \mathbf{T}_{\mathbf{g}}-$ Glass transition temperature ${ }^{\circ} \mathrm{C}$;

$\mathbf{T}_{\mathbf{s}}-$ Glass softening temperature $\left({ }^{\circ} \mathrm{C}\right) ; \mathbf{T}_{\mathbf{h}}$ - Glass crack-healing temperature $\left({ }^{\circ} \mathrm{C}\right)$

*UMR glasses

Table 2. Electrical properties of glasses between $25-500^{\circ} \mathrm{C}$ and different frequencies.

\begin{tabular}{|c|c|c|c|c|c|c|c|c|c|}
\hline \multirow{2}{*}{$\begin{array}{c}\text { Glass Type/ } \\
\text { Thickness } \\
(\mathbf{m m})\end{array}$} & \multicolumn{9}{|c|}{$\mathbf{1 ~ H z}$} \\
\cline { 2 - 10 } & $25^{\circ} \mathrm{C}$ & $400^{\circ} \mathrm{C}$ & $500^{\circ} \mathrm{C}$ & $25^{\circ} \mathrm{C}$ & $400^{\circ} \mathrm{C}$ & $500^{\circ} \mathrm{C}$ & $25^{\circ} \mathrm{C}$ & $400^{\circ} \mathrm{C}$ & $500^{\circ} \mathrm{C}$ \\
\hline Glass 3/0.47 & $3.9 \mathrm{E}+9$ & $2.8 \mathrm{E}+4$ & $3.8 \mathrm{E}+3$ & $1.8 \mathrm{E}+4$ & $2.5 \mathrm{E}+4$ & $3.3 \mathrm{E}+3$ & $1.0 \mathrm{E}+2$ & $4.5 \mathrm{E}+2$ & $2.3 \mathrm{E}+2$ \\
\hline Glass 4/0.53 & $5.7 \mathrm{E}+8$ & $3.6 \mathrm{E}+9$ & $2.2 \mathrm{E}+8$ & $3.9 \mathrm{E}+3$ & $7.5 \mathrm{E}+3$ & $2.0 \mathrm{E}+4$ & $7.9 \mathrm{E}+2$ & $7.9 \mathrm{E}+2$ & $8.0 \mathrm{E}+2$ \\
\hline Glass $5 / 0.56$ & $2.5 \mathrm{E}+8$ & $2.7 \mathrm{E}+8$ & $2.0 \mathrm{E}+8$ & $2.9 \mathrm{E}+3$ & $2.3 \mathrm{E}+4$ & $1.6 \mathrm{E}+4$ & $7.8 \mathrm{E}+2$ & $7.9 \mathrm{E}+2$ & $7.6 \mathrm{E}+2$ \\
\hline
\end{tabular}




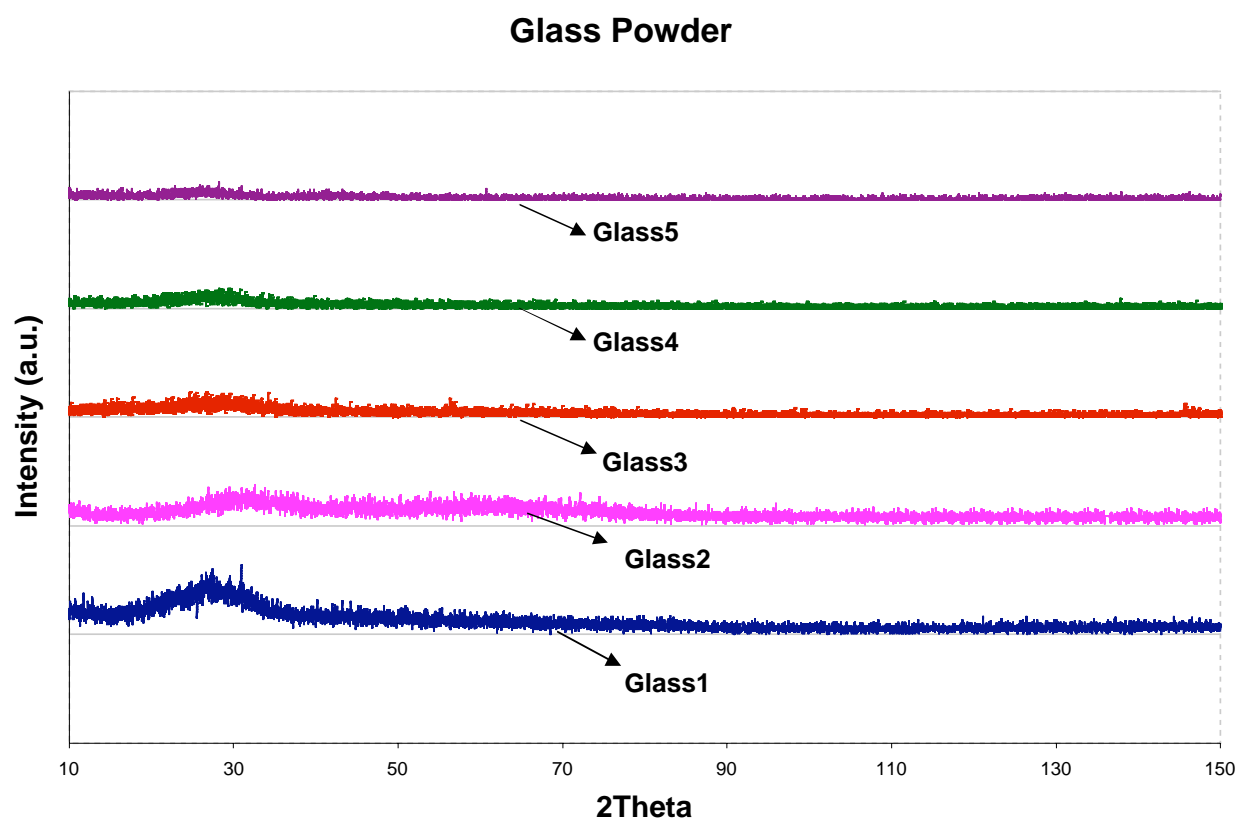

Fig. 1. X-ray diffraction of glass powders in the as-received state indicating amorphous structure. 
DE-FC26-04NT42227 - Innovative Seals for Solid Oxide Fuel Cells (SOFC)

\section{Expansion}

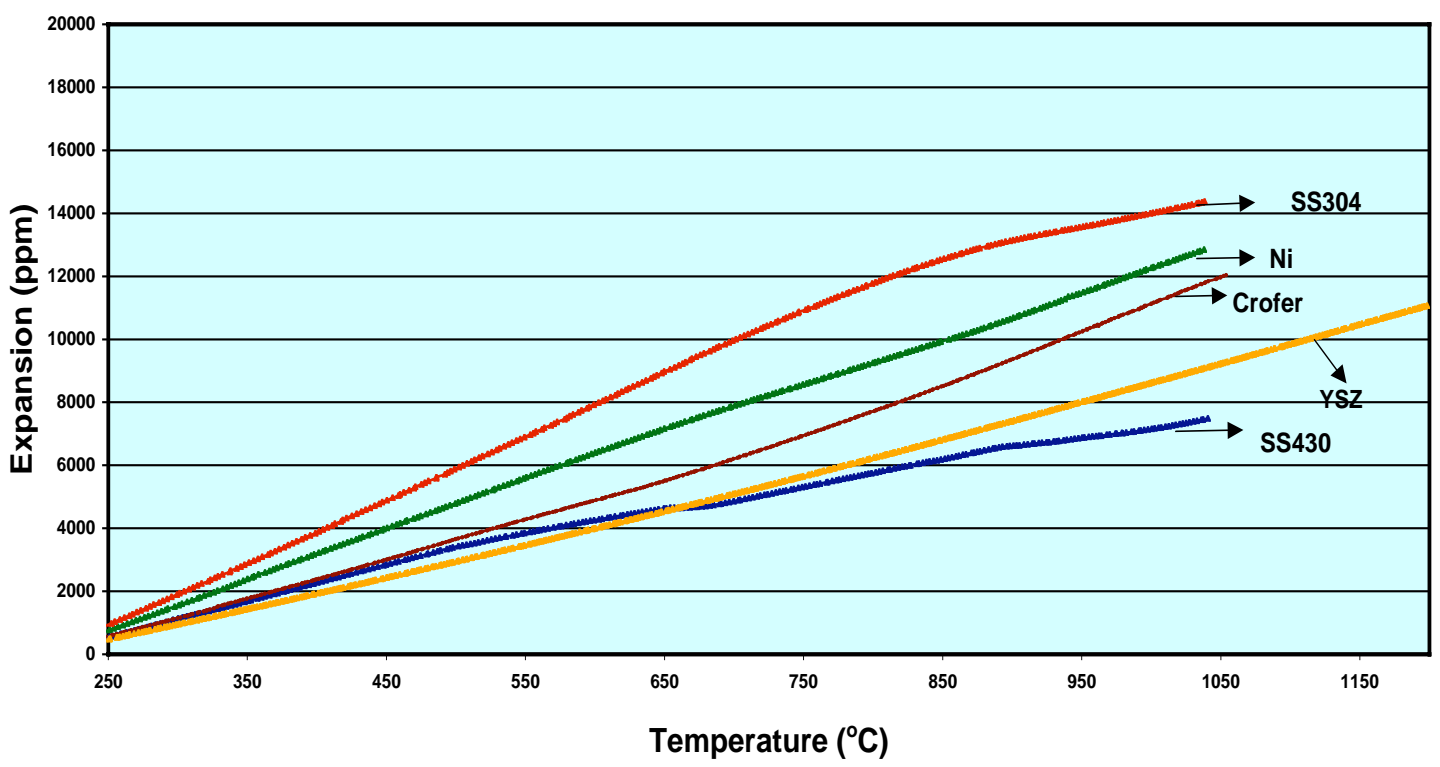

Fig. 2. Effect of temperature on thermal expansion of Crofer, SS 430, Nickel, and SS 304 metals. Expansion behavior of YSZ is also shown for comparison.

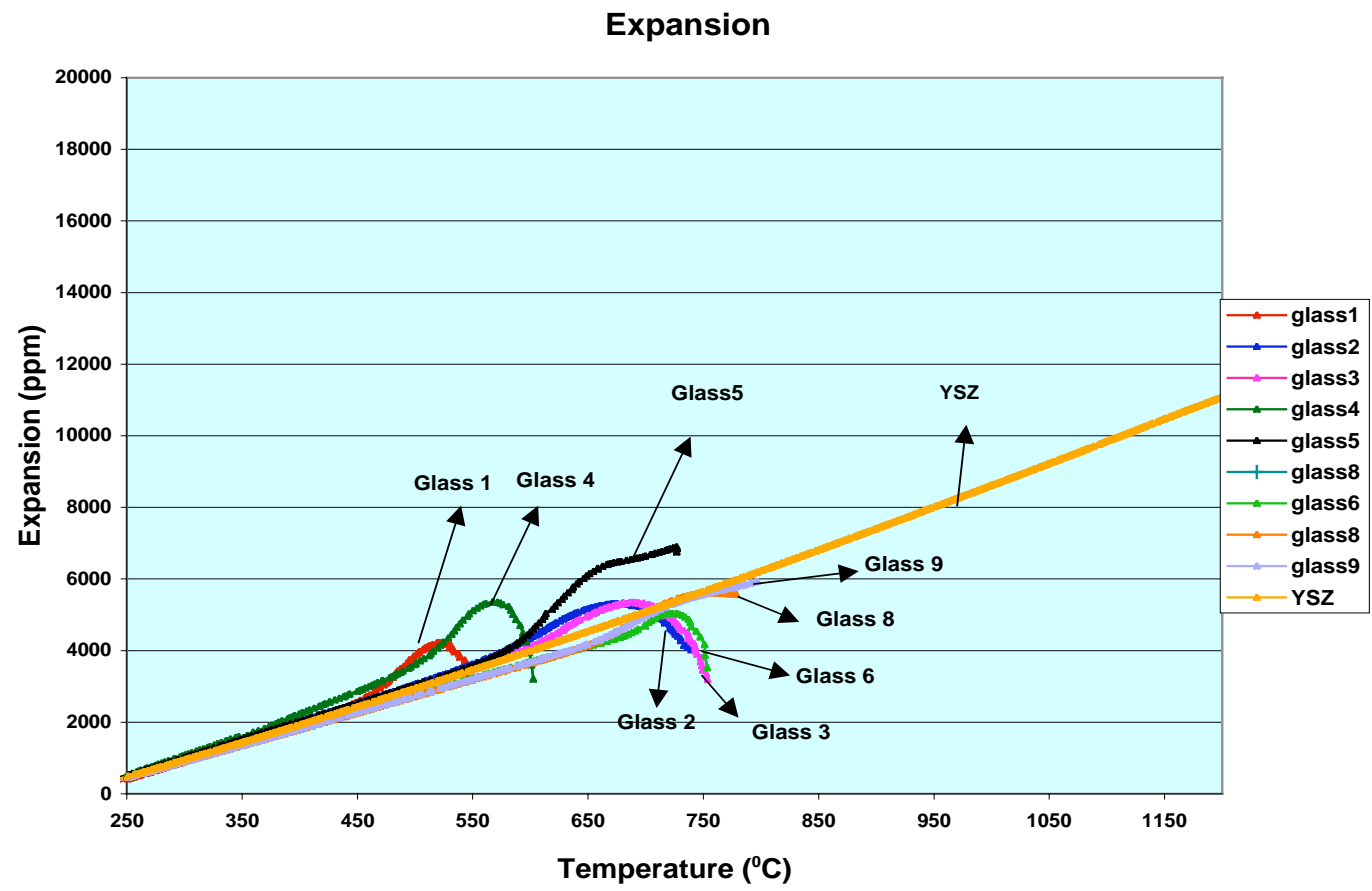

Fig. 3. Effect of temperature on thermal expansion of glasses selected for study. Expansion behavior of YSZ is also shown for comparison. 
DE-FC26-04NT42227 - Innovative Seals for Solid Oxide Fuel Cells (SOFC)

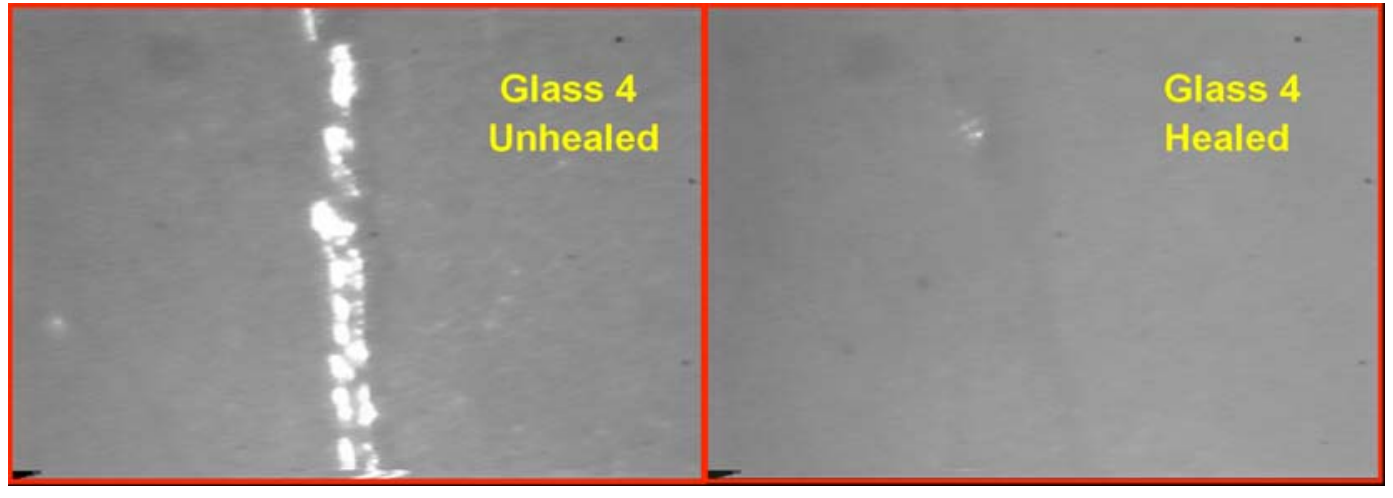

Fig. 4. Still photograph of crack on glass4 sample before and after healing.

\section{Glasses on Crofer}
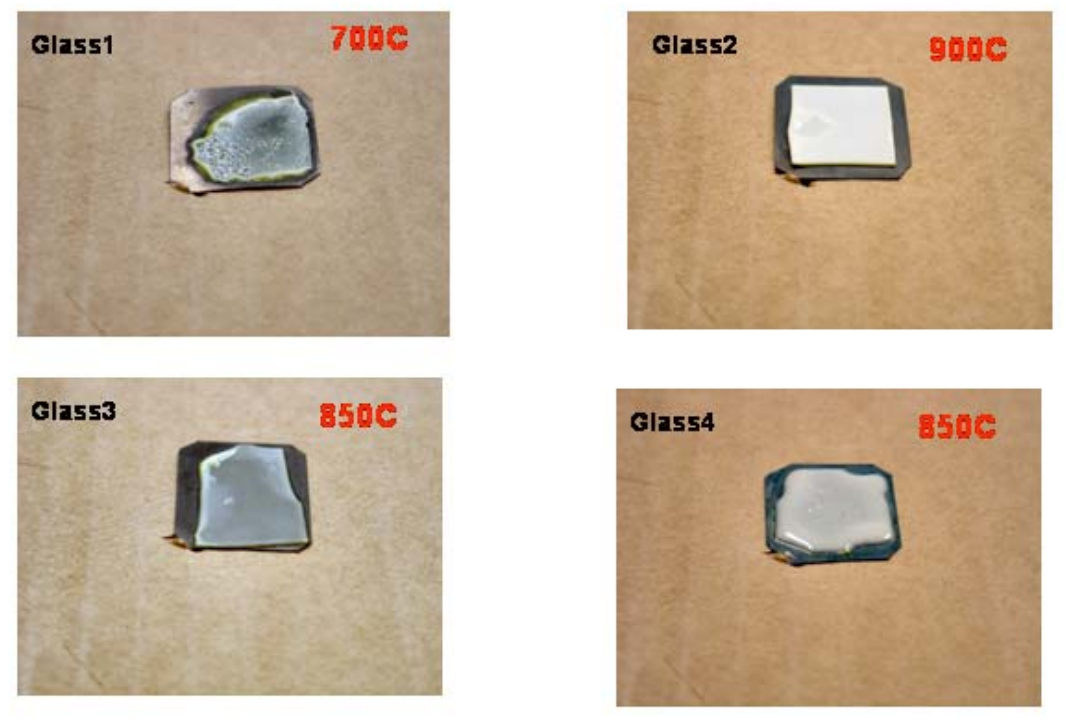

Fig. 5. 


\section{Glasses on SS430}
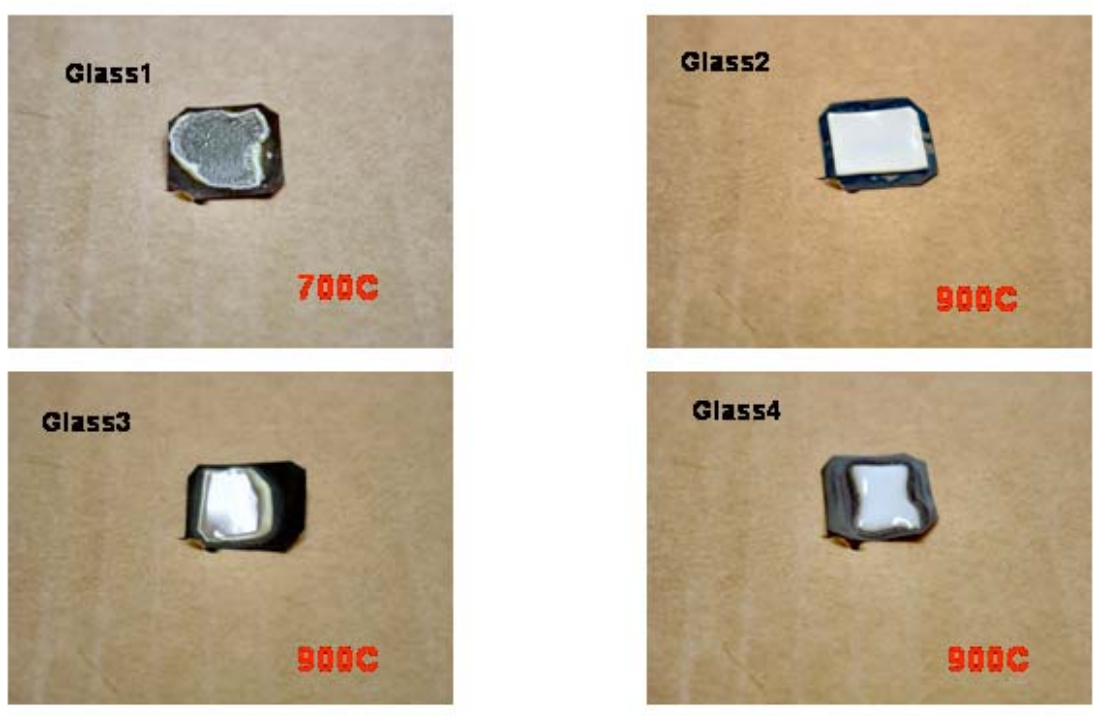

\section{Glasses on $\mathrm{Ni}$}
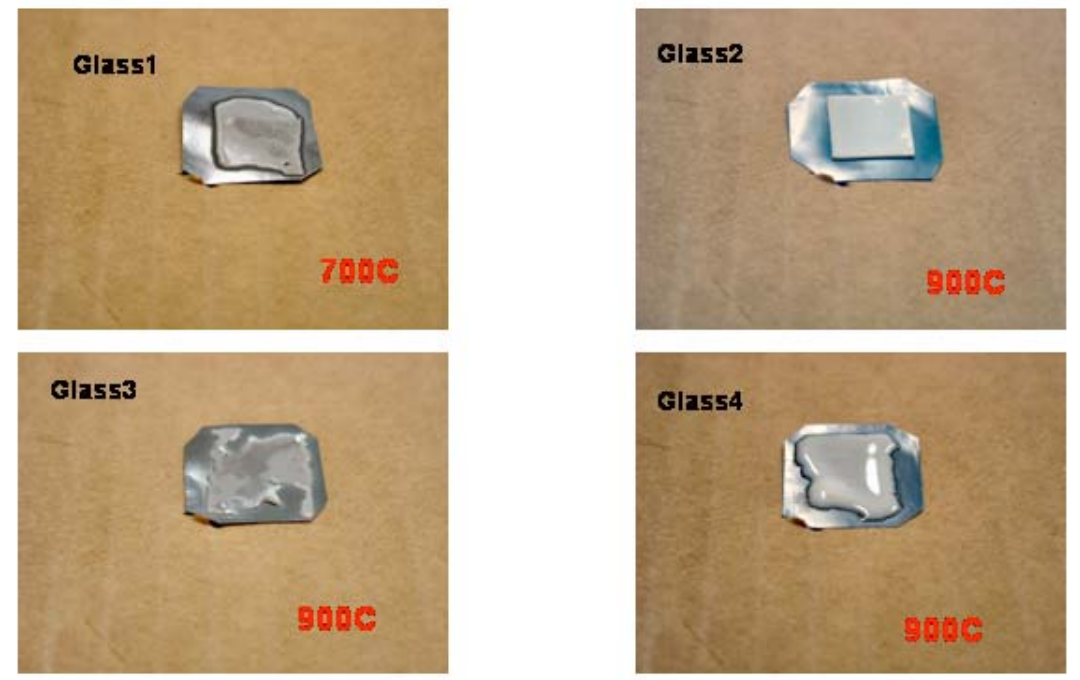

Fig. 5. Wetting behavior of Glasses on Crofer, SS 430, and Nickel metals at different temperatures to illustrate the suitability of glasses for making glass-metal seals. 


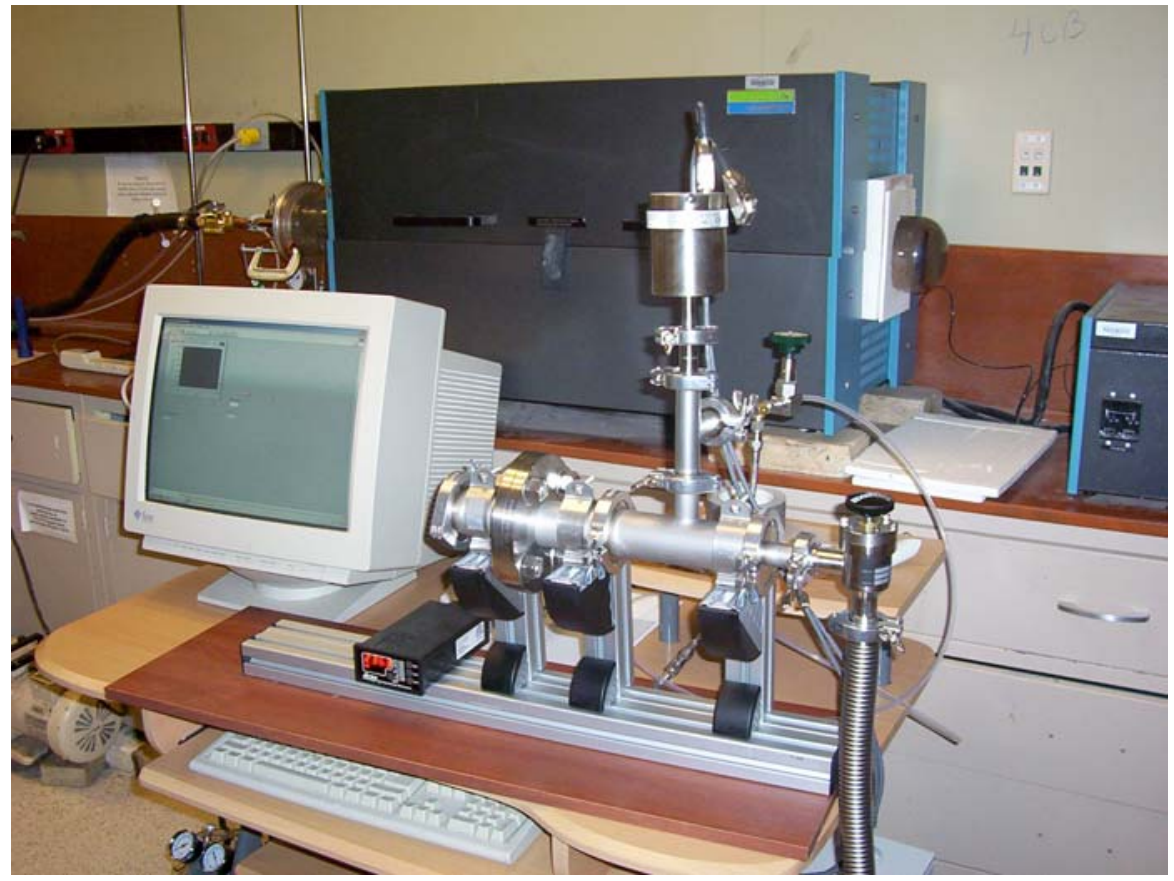

Fig. 6. Facility for leak testing and continuous monitoring of SOFC seals both at room temperature and up to $1200^{\circ} \mathrm{C}$ under a variety of pressure drops.

Pressure Drop with Time

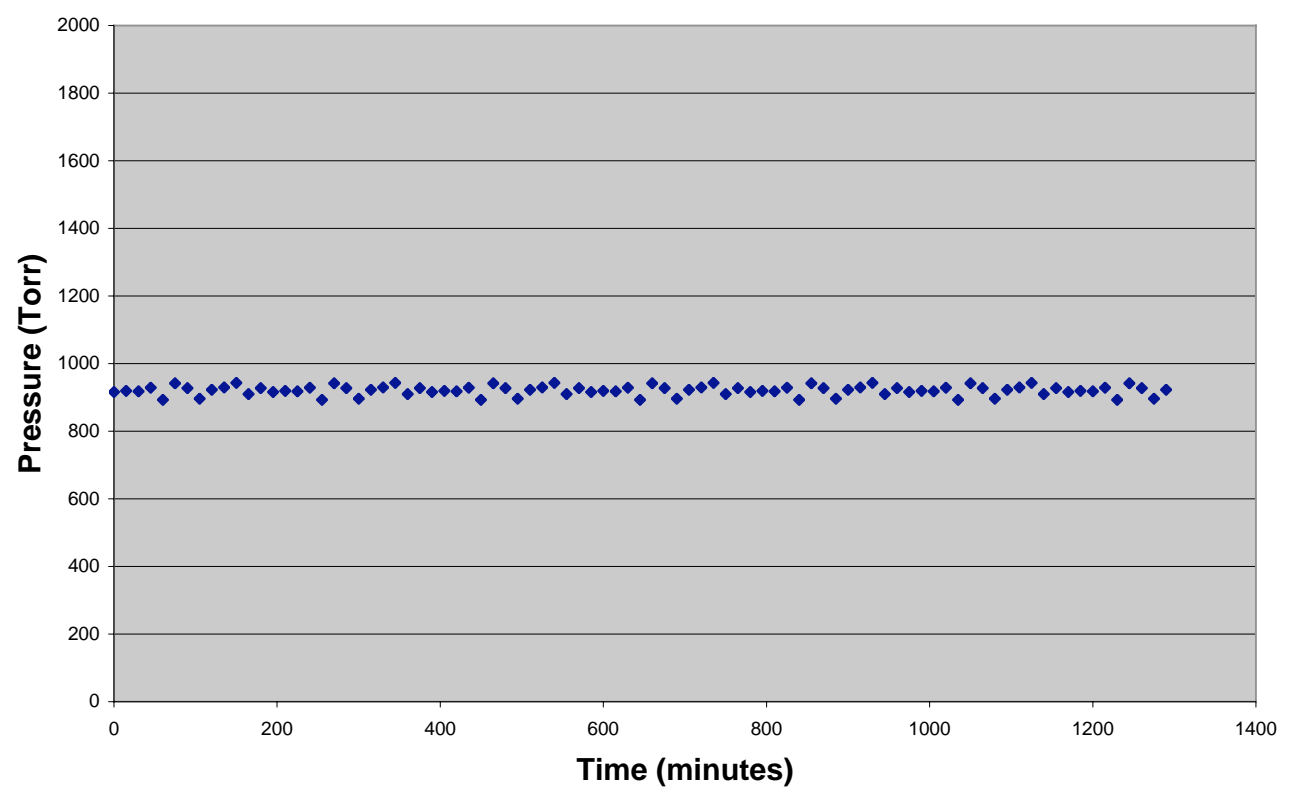

Fig. 7. Pressure-time plot of the leak test station. 
High Temp Leak Rate Seal 26

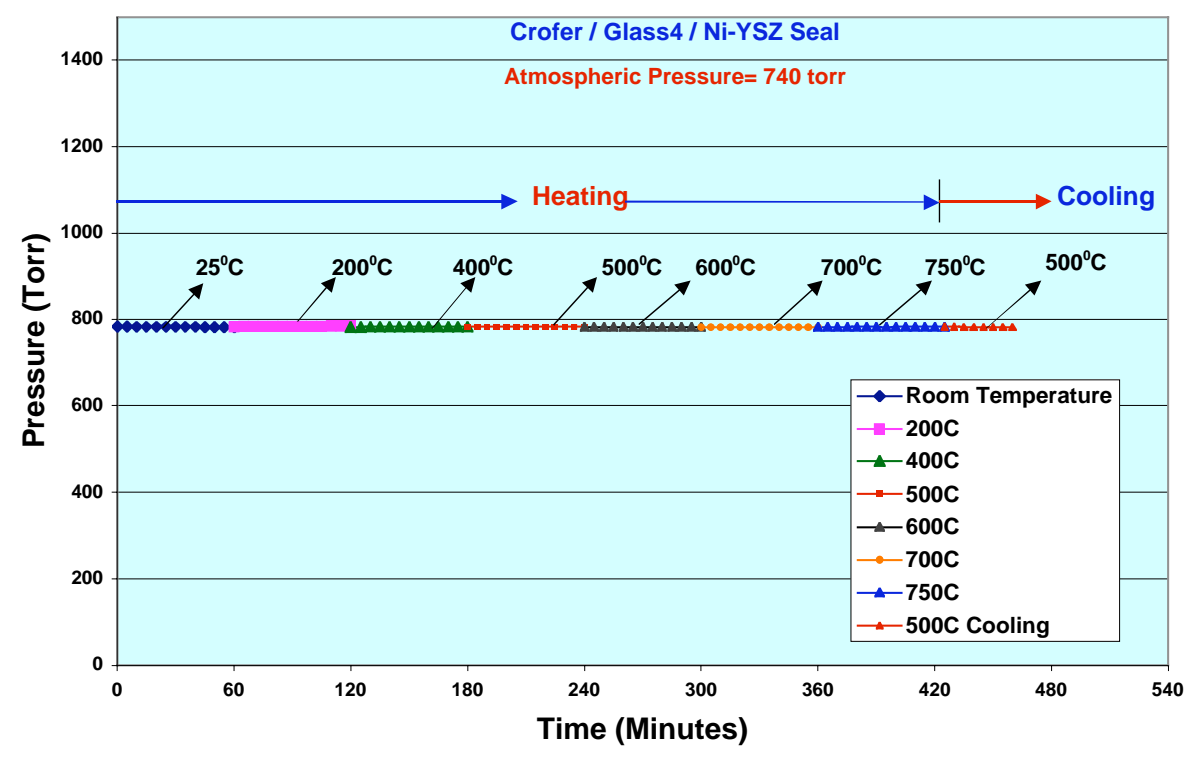

Fig. 8. Demonstration of high-temperature hermetic seals made from Crofer-Glass 4-Ni/YSZ. The electrolyte was anode-supported. The seal was tested for 1 hour at each temperature during heating and for 0.5 hour during cooling.

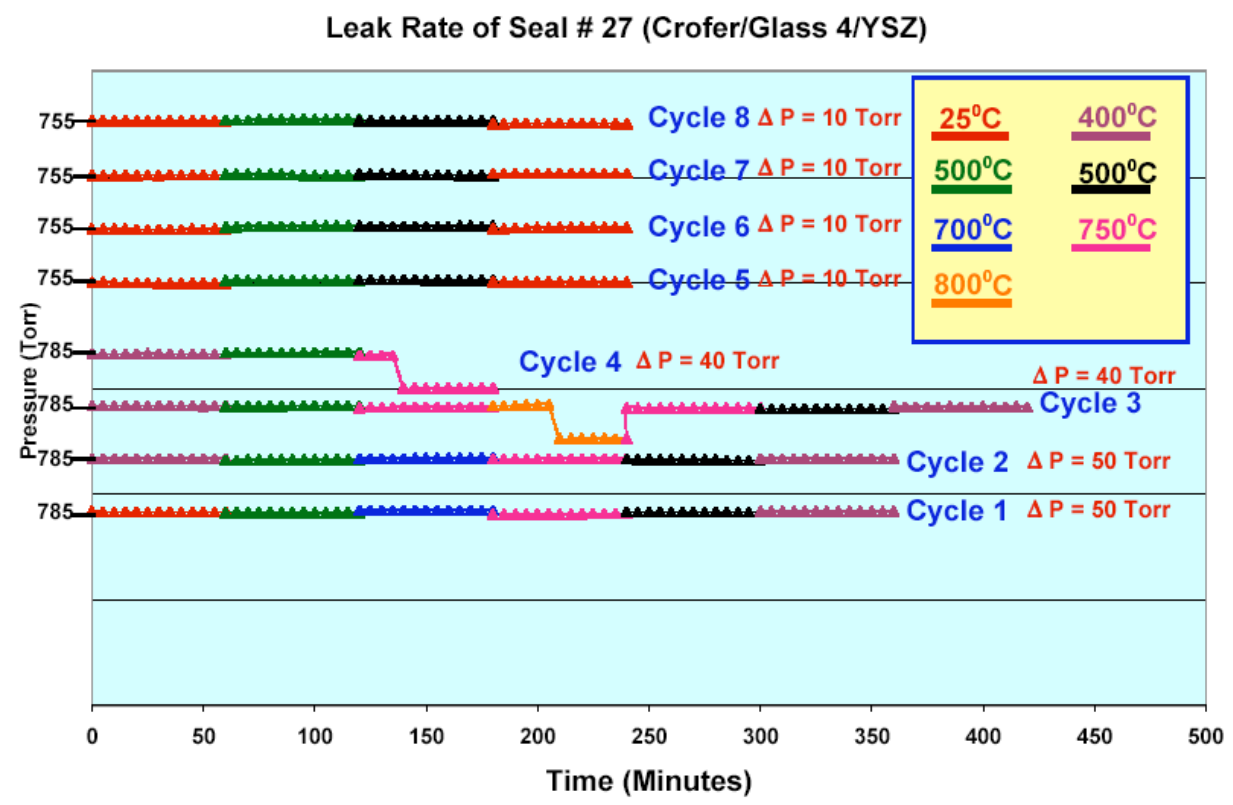

Fig. 9. Pressure-time plots of the leak tests of a Crofer-Glass 4-YSZ seal. This seal developed leaks in the $3^{\text {rd }}$ and $4^{\text {th }}$ cycles and then healed to create hermetic seal. The data shows hermetic seals after healing to $8^{\text {th }}$ cycle. 


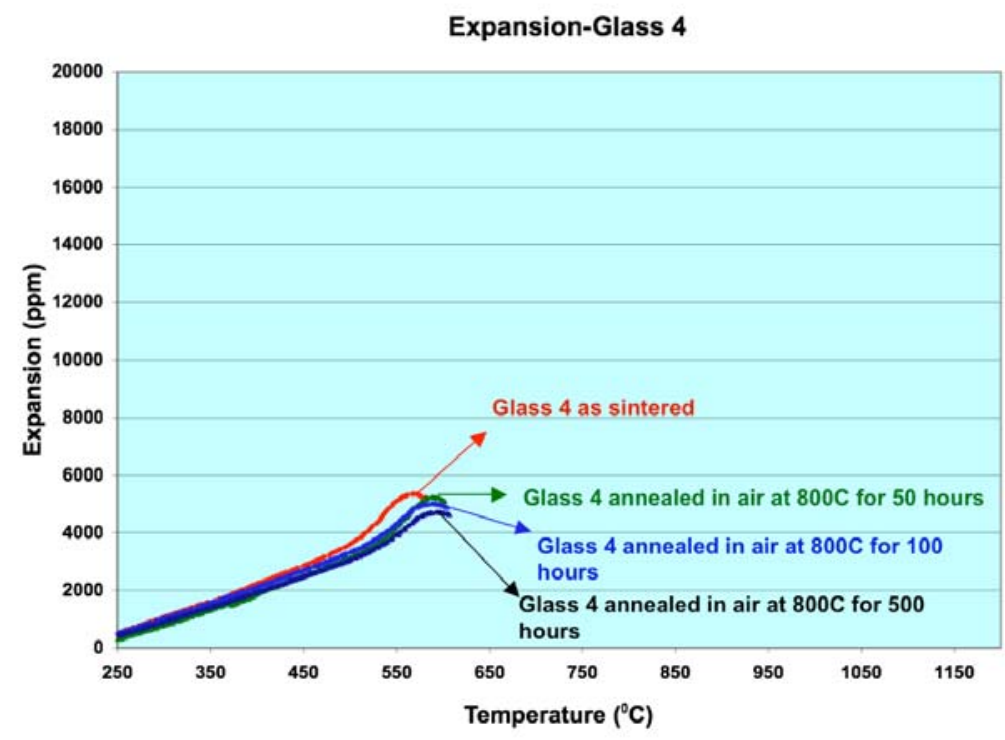

Fig. 10. Influence of thermal annealing at $800^{\circ} \mathrm{C}$ up to $500 \mathrm{hrs}$. on the expansion behavior of glass 4 . Note an insignificant change in the softening temperature and expansion behaviors.

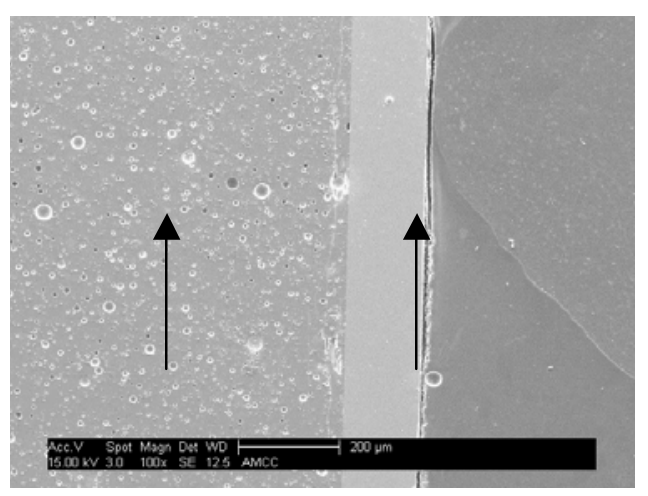

Glass-3
Crofer

(a)

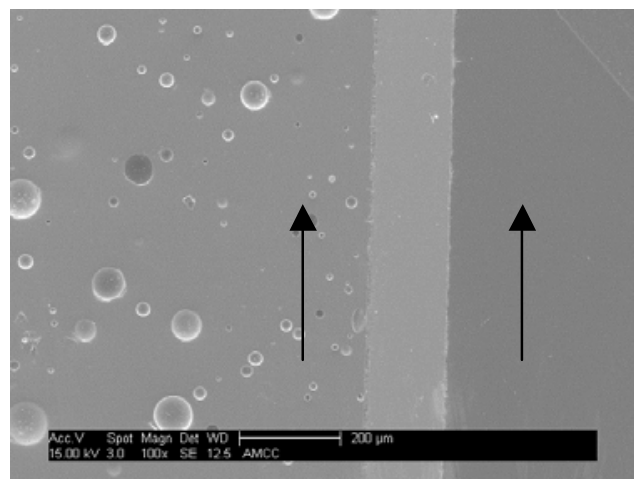

Glass-4 Crofer

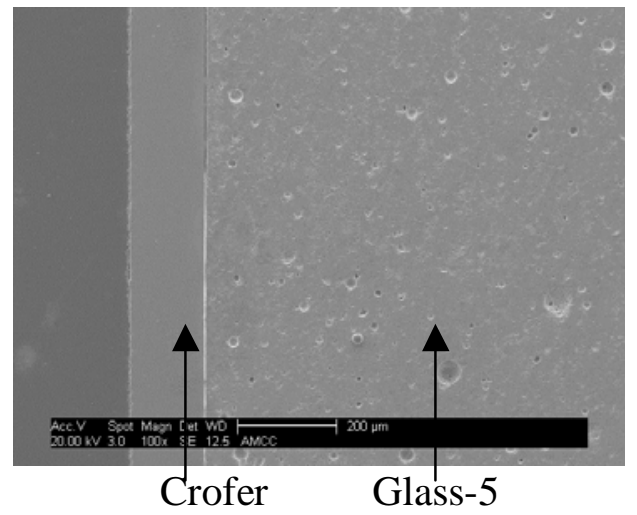

(b)

(c)

Fig. 11. SEM micrographs of (a) Crofer-Glass 3, Crofer-Glass 4, and Crofer-Glass 5 interactions for samples annealed at $800^{\circ} \mathrm{C}$ for 200 hours. There is an insignificant interaction under these conditions. 


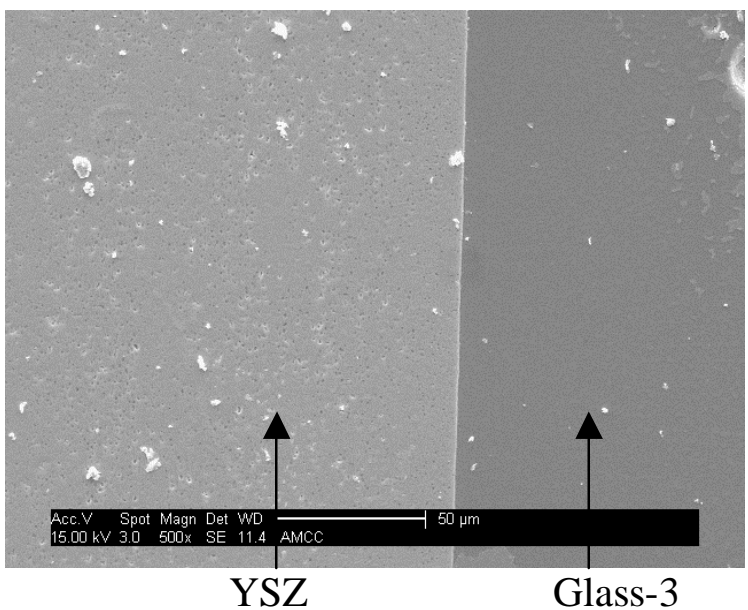

(a)

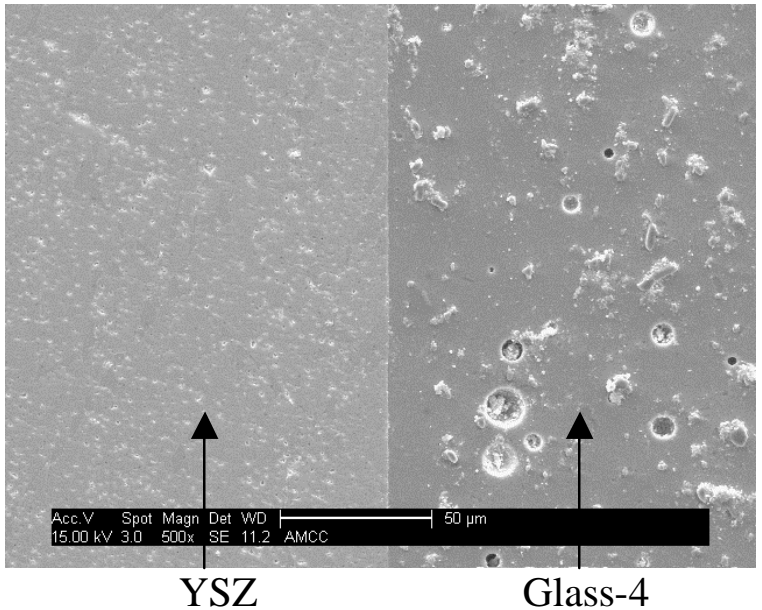

(b)

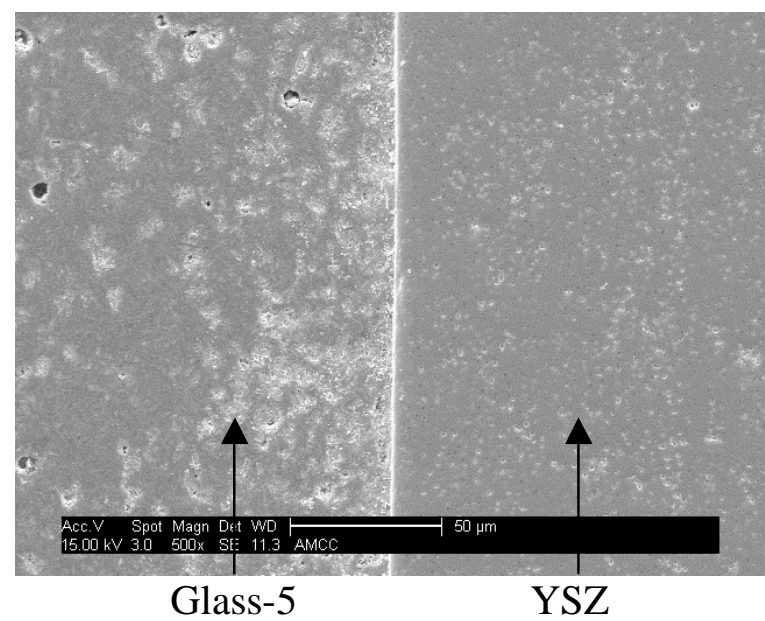

(c)

Fig. 12. SEM micrographs of (a) YSZ-Glass 3, YSZ-Glass 4, and YSZ-Glass 5 interactions for samples annealed at $800^{\circ} \mathrm{C}$ for 200 hours. There is an insignificant interaction under these conditions 


\section{DE-FC26-04NT42227 - Innovative Seals for Solid Oxide Fuel Cells (SOFC)}

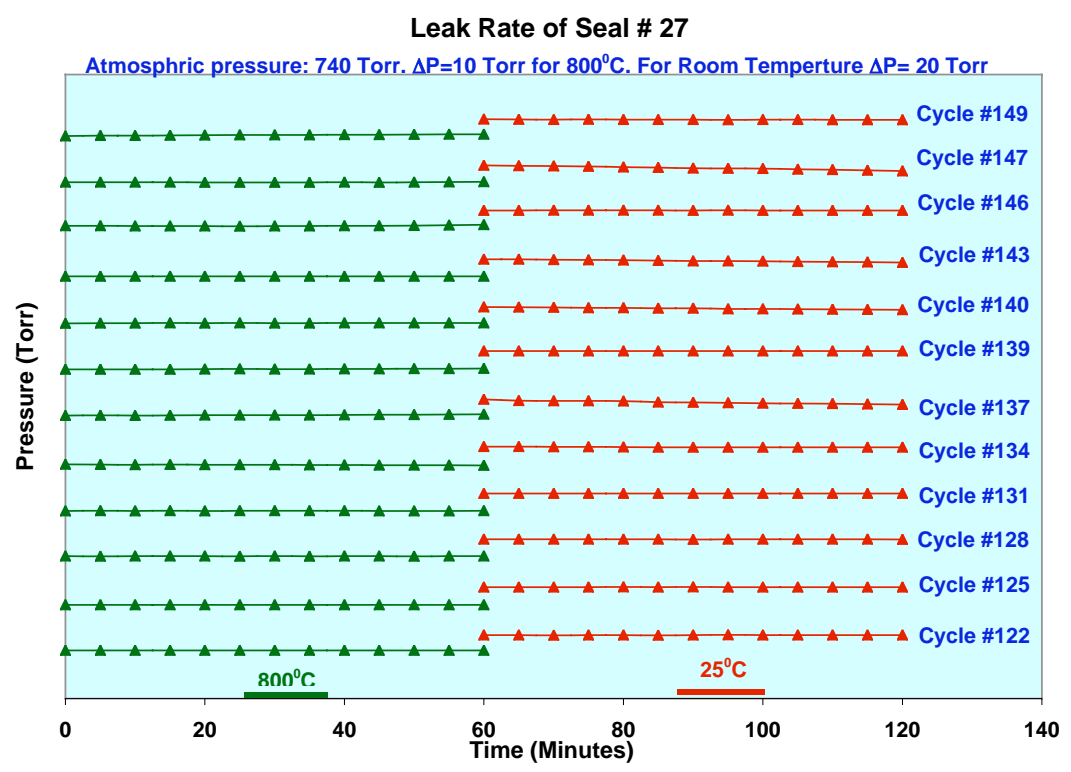

Fig. 13. Pressure-time plots between 122 and 149 thermal cycles between $25-800^{\circ} \mathrm{C}$ of the leak tests of the seal made using Crofer-Glass 4-YSZ. Note a small leak in 137 and 147 cycles at $25^{\circ} \mathrm{C}$ and recovery in 137 and 149 cycles.

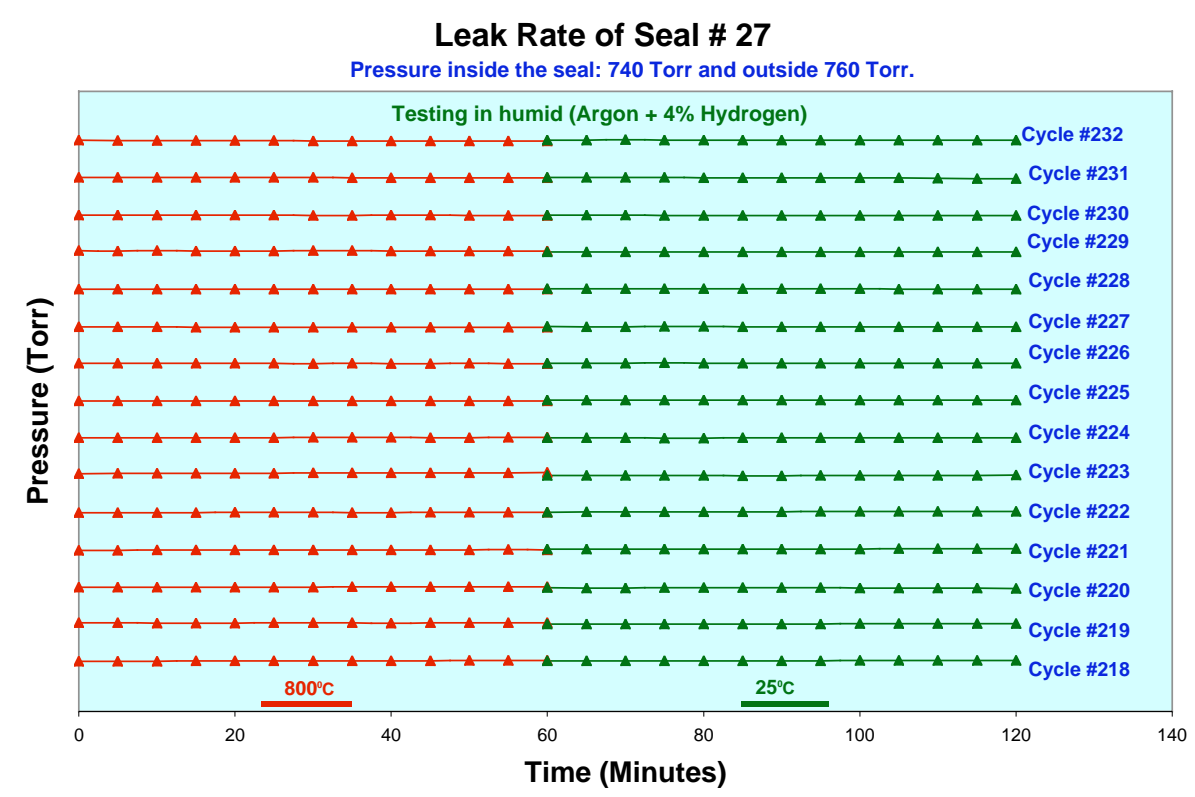

Fig. 14. Pressure-time plots between 218 and 232 thermal cycles of the leak tests of the seal made using Crofer-Glass 4-YSZ. Effect of leak test in $\mathrm{Ar}-4 \% \mathrm{H}_{2}-6 \% \mathrm{H}_{2} \mathrm{O}$. This seal continues to show hermetic behavior between $25-800^{\circ} \mathrm{C}$. 
DE-FC26-04NT42227 - Innovative Seals for Solid Oxide Fuel Cells (SOFC)

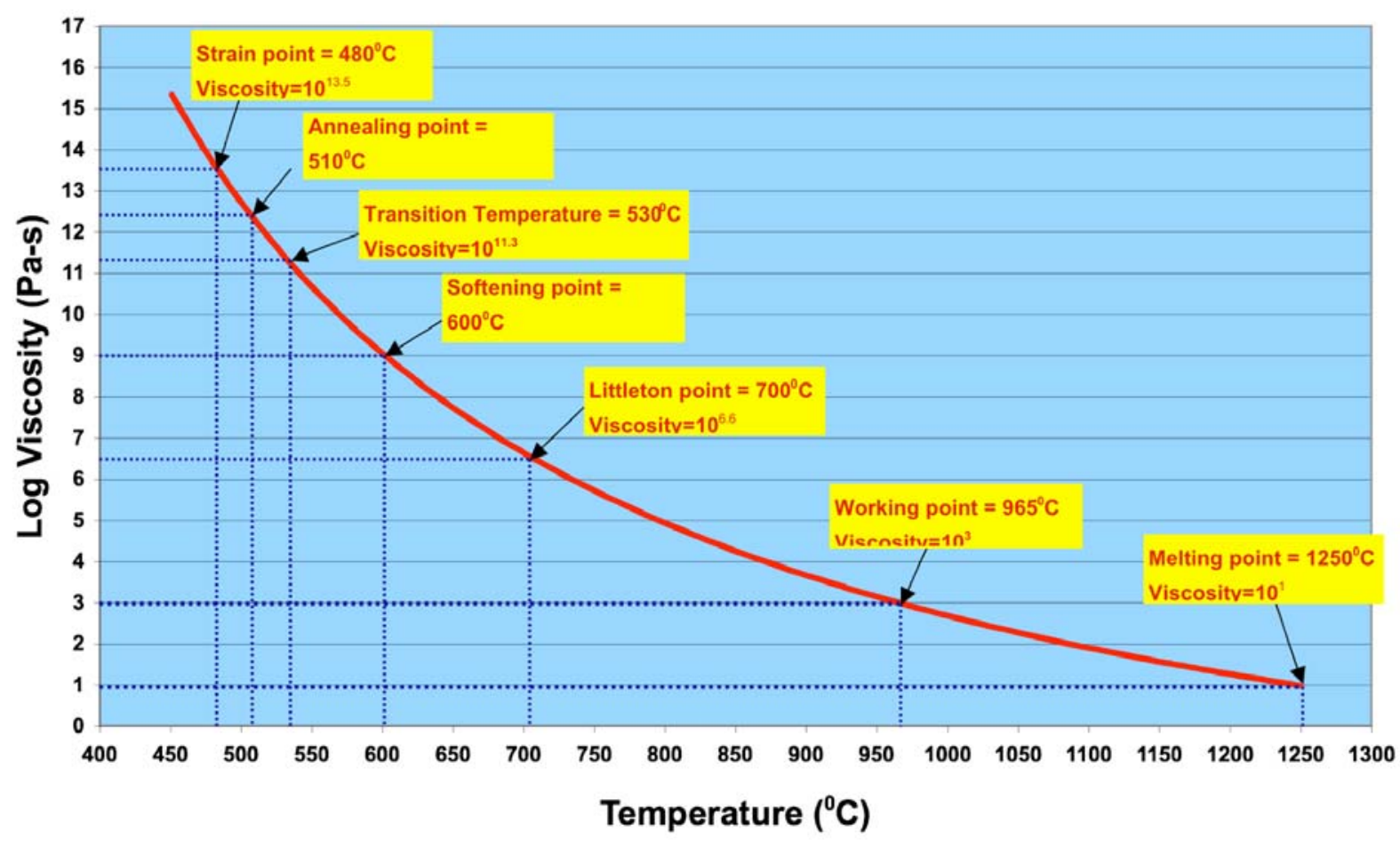

Fig. 15. Viscosity temperature data for a self-healing glass over a range of temperature.

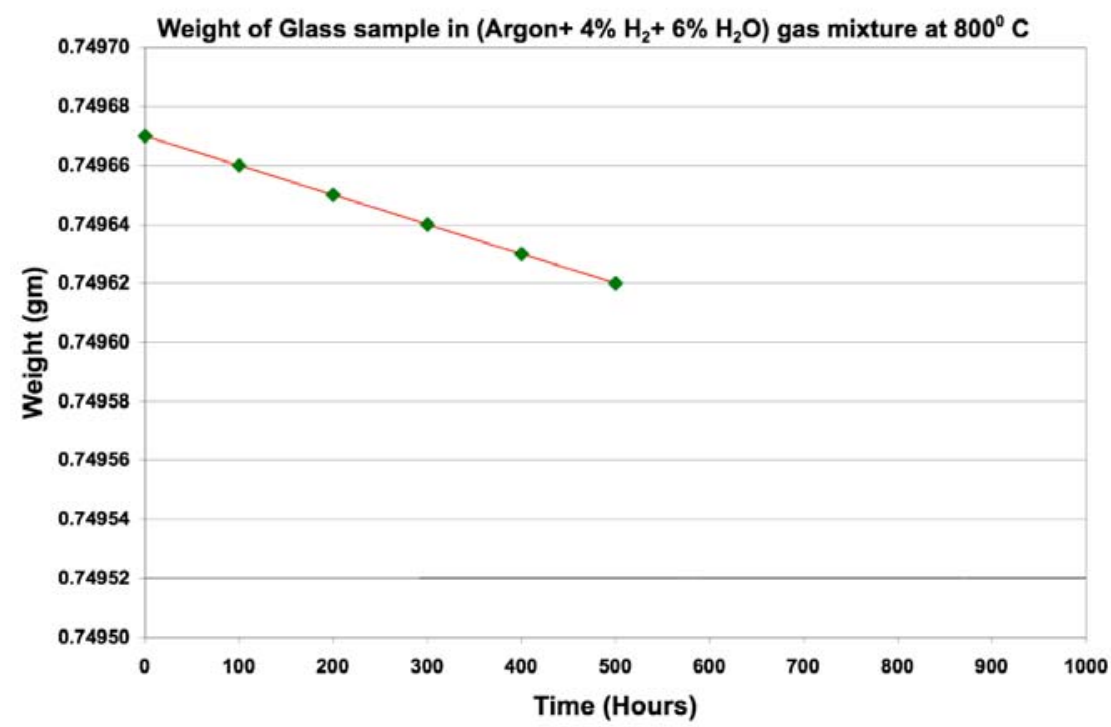

Fig. 16 (a) 
DE-FC26-04NT42227 - Innovative Seals for Solid Oxide Fuel Cells (SOFC)

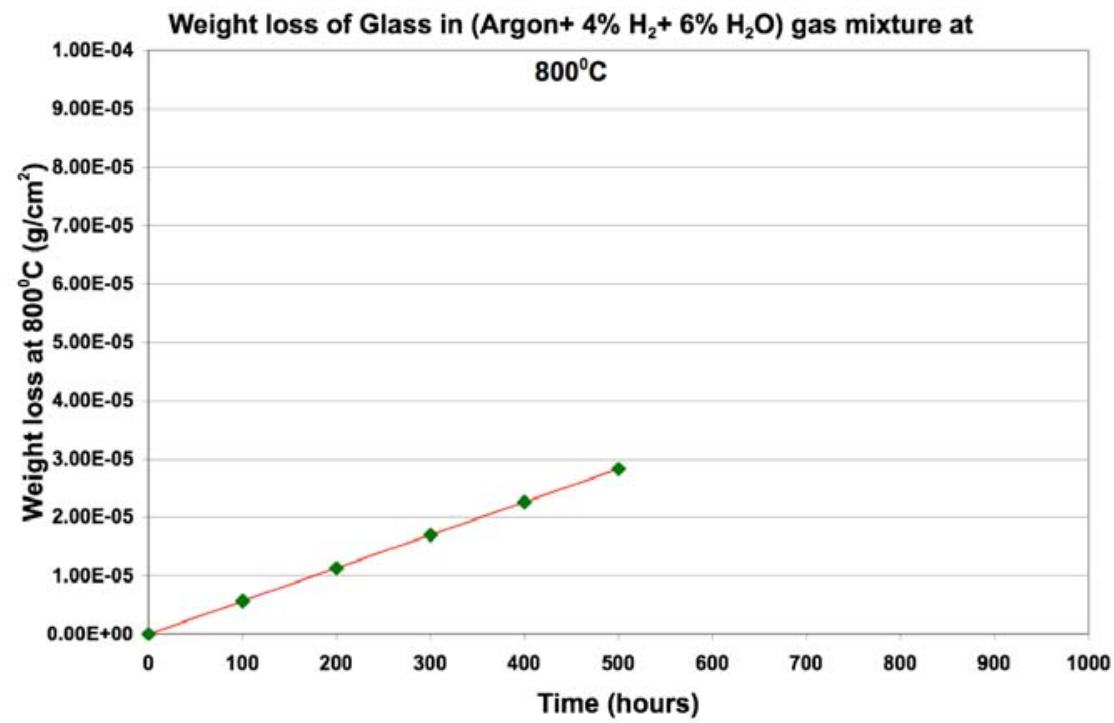

(b)

Fig. 16. Weight loss data for the self-healing glass annealed in flowing $\mathrm{Ar}-4 \% \mathrm{H}_{2}-6 \% \mathrm{H}_{2} \mathrm{O}$ at $800{ }^{\circ} \mathrm{C}$ over a time period of 500 hours showing (a) weight change Vs time and (b) weight loss $/ \mathrm{cm}^{2} \mathrm{Vs}$ time.

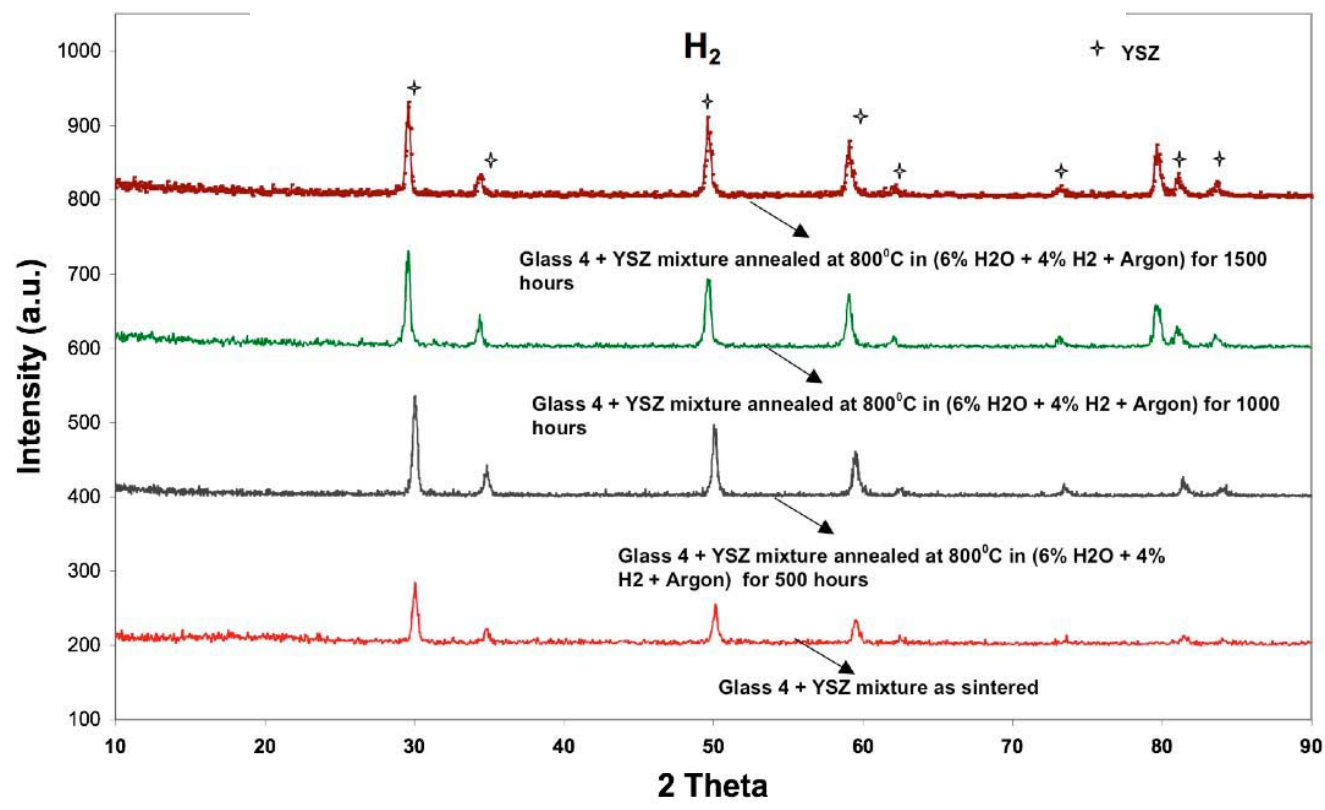

Fig. 17. Effect of annealing at $800^{\circ} \mathrm{C}$ in $\mathrm{Ar}-4 \% \mathrm{H}_{2}-6 \% \mathrm{H}_{2} \mathrm{O}$ moist fuel environment on the stability of the glass containing 5\% YSZ filler on x-ray diffraction behavior. Note a lack of crystallization of the glass-5\%YSZ upon annealing for 1500 hours. 
DE-FC26-04NT42227 - Innovative Seals for Solid Oxide Fuel Cells (SOFC)

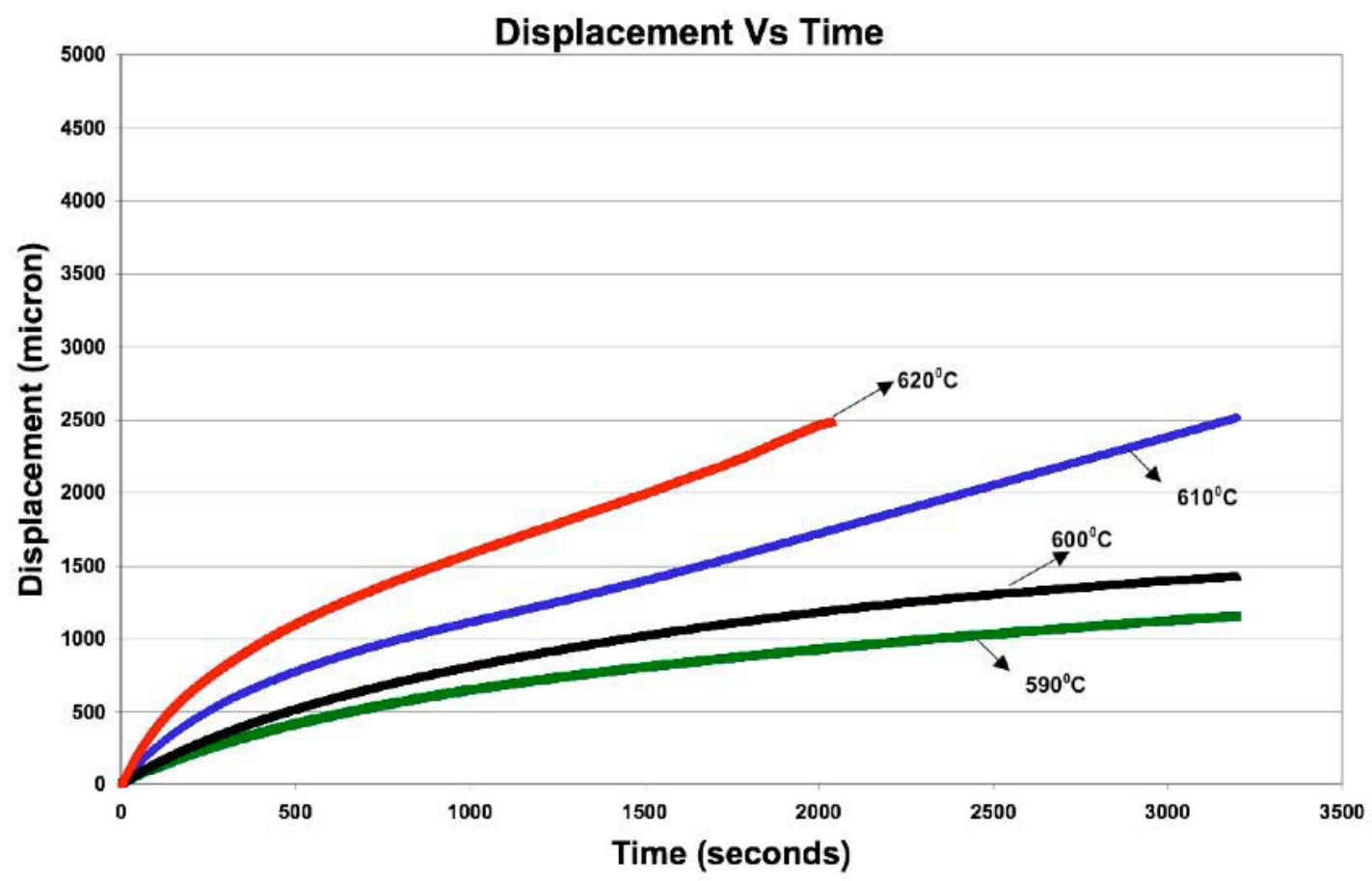

Fig. 18. Creep (displacement-time) plots of a self-healing glass sample tested at high temperatures at a load of $10 \mathrm{~N}$ in flexure mode. The data on creep rates are useful for assessing deformation of the glass under load in seals as well as in modeling of the seal behavior in a stack.

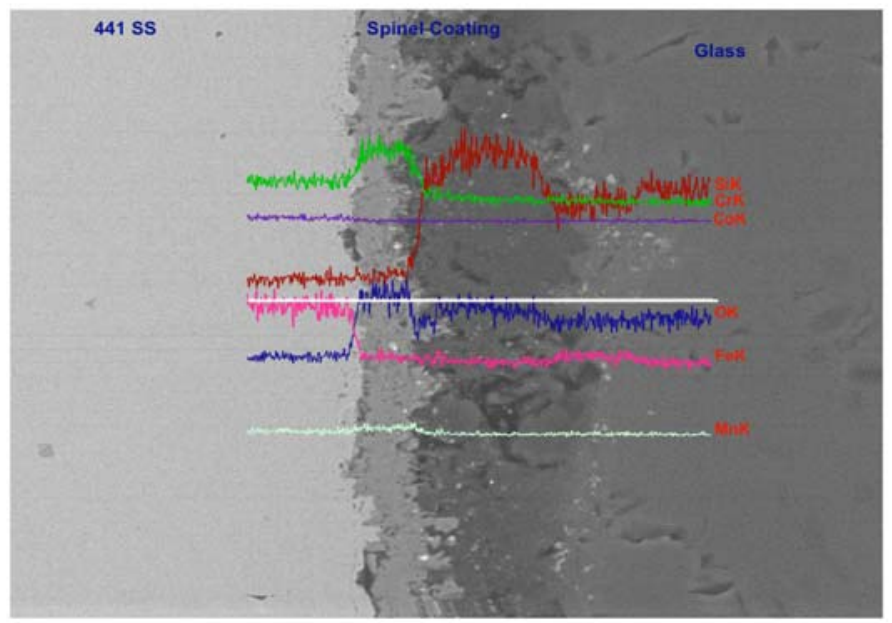

Fig. 19. SEM and EDAX results on compatibility of glass in contact with $441 \mathrm{SS}$ annealed in air at $800^{\circ} \mathrm{C}$ for 1000 hours. 


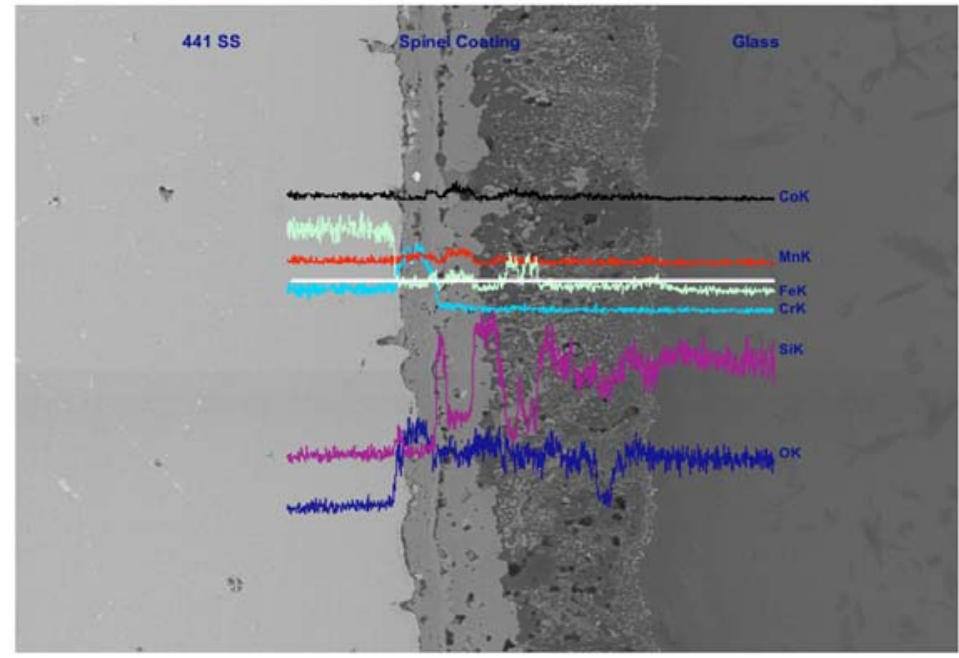

Fig. 20. SEM and EDAX results on compatibility of glass in contact with CoMn Spinel-coated $441 \mathrm{SS}$ annealed in air at $800^{\circ} \mathrm{C}$ for 1000 hour

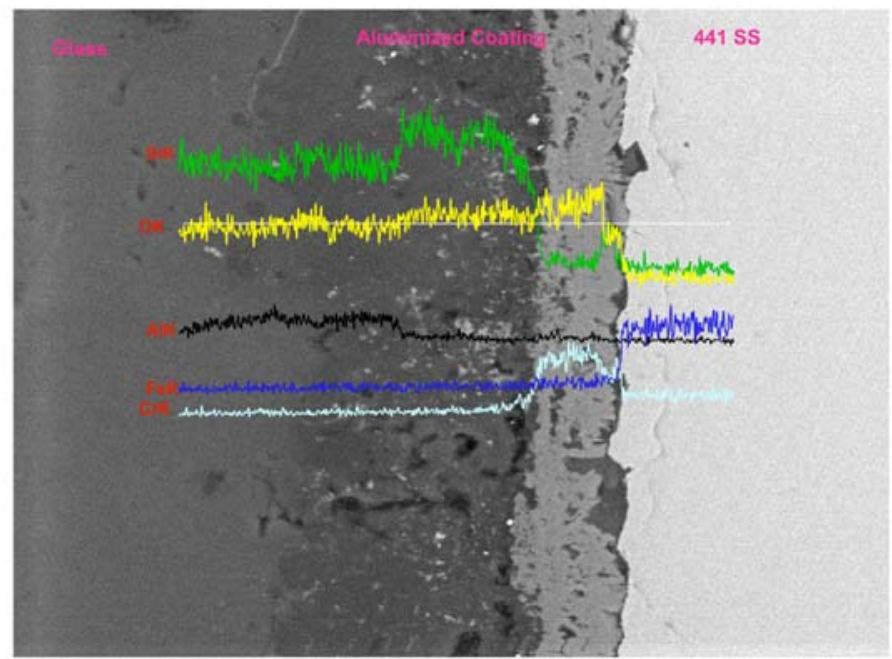

Fig. 21. SEM and EDAX results on compatibility of the glass in contact with aluminized 441 SS annealed in air at $800^{\circ} \mathrm{C}$ for 1000 hours. 


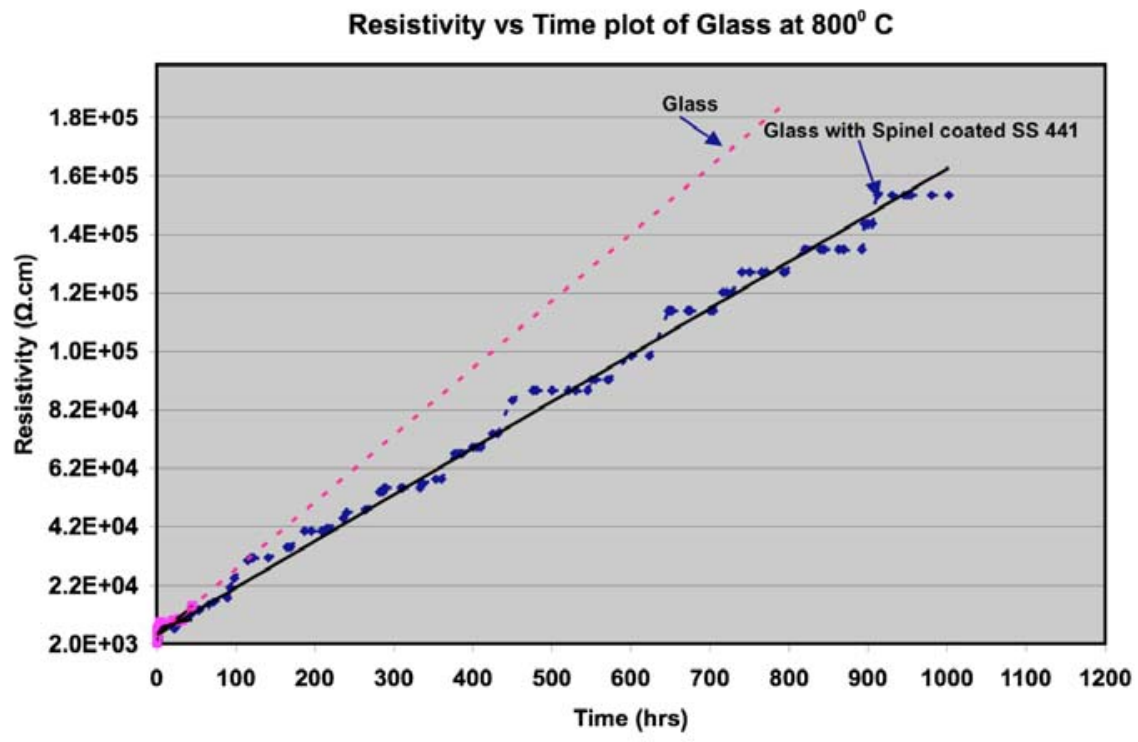

Fig. 22. Resitivity-time data of the CoMn Spinel-Coated 441 SS in contact with a glass annealed at $800^{\circ} \mathrm{C}$ in air for 1000 hours. The data on a glass alone is also shown for comparison.

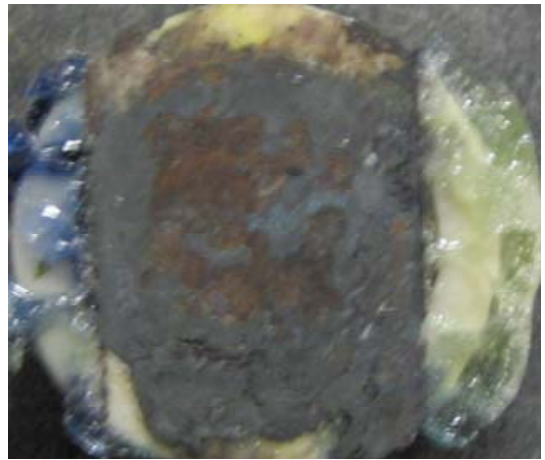

(a)

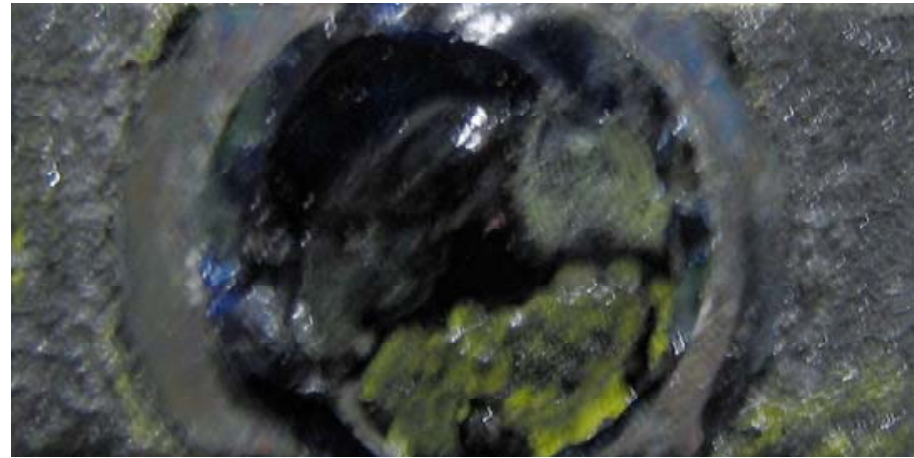

(b)

Fig. 23. Photographs from CoMn spinel-coated $441 \mathrm{SS}$ after testing in air at $800^{\circ} \mathrm{C}$ for 1000 hours under an applied voltage of $1 \mathrm{~V}$. (a) near the negative electrode and (b) near the positive electrode. Note bluish coloration of the glass after testing. 
DE-FC26-04NT42227 - Innovative Seals for Solid Oxide Fuel Cells (SOFC)

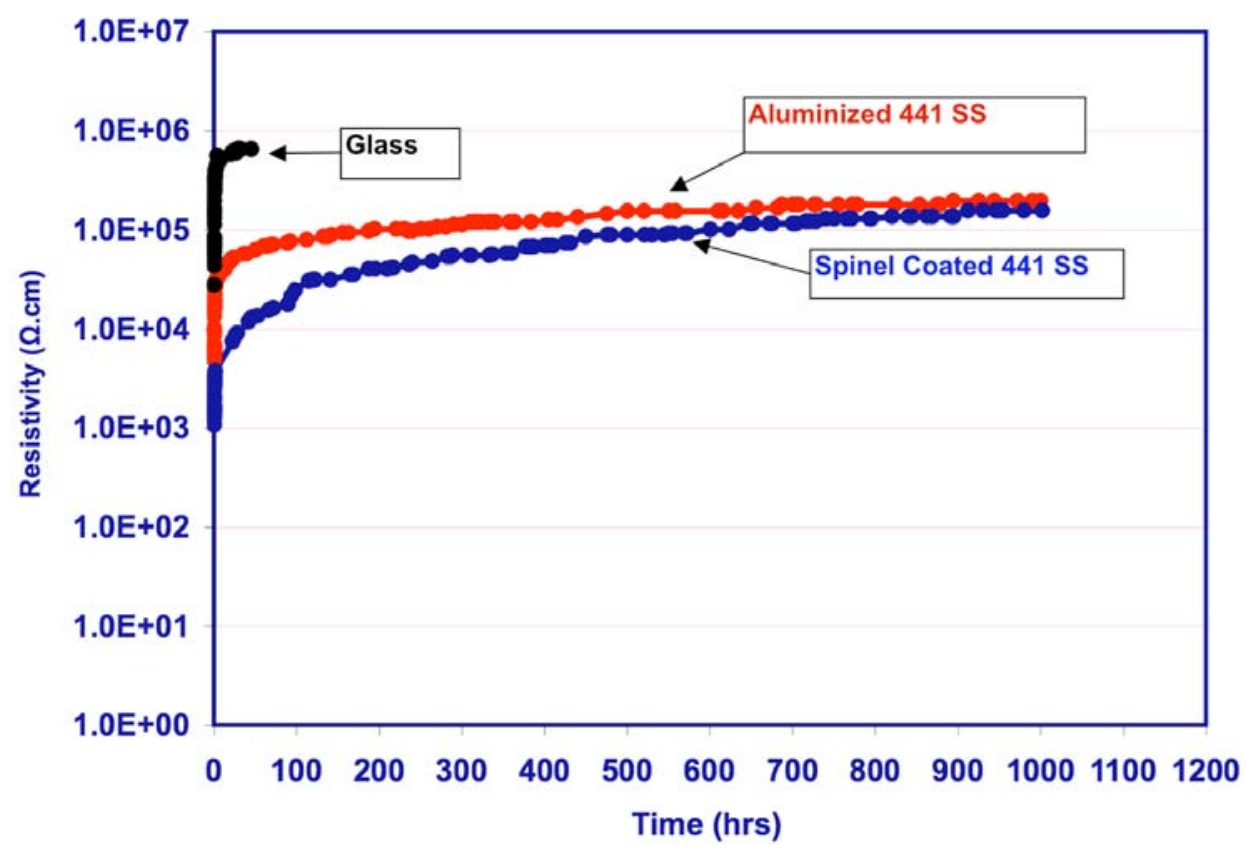

Fig. 24. Resitivity-time data of the CoMn Spinel-Coated and aluminized 441 SS in contact with a glass annealed at $800^{\circ} \mathrm{C}$ in air for 1000 hours. The data on a glass alone is also shown for comparison. 